\title{
Revisiting the taxonomy of the family Circoviridae: establishment of the genus Cyclovirus and removal of the genus Gyrovirus
}

\author{
Karyna Rosario $^{1}$ Mya Breitbart ${ }^{1} \cdot$ Balázs Harrach $^{2} \cdot$ Joaquim Segalés $^{3,4}$. \\ Eric Delwart $^{5,6} \cdot$ Philippe Biagini $^{7}$ - Arvind Varsani ${ }^{8,9}$ (i)
}

Received: 9 December 2016/Accepted: 29 December 2016/Published online: 2 February 2017

(C) Springer-Verlag Wien 2017

\begin{abstract}
The family Circoviridae contains viruses with covalently closed, circular, single-stranded DNA (ssDNA) genomes, including the smallest known autonomously replicating, capsid-encoding animal pathogens. Members of this family are known to cause fatal diseases in birds and pigs and have been historically classified in one of two genera: Circovirus, which contains avian and porcine pathogens, and Gyrovirus, which includes a single species (Chicken anemia virus). However, over the course of the past six years, viral metagenomic approaches as well as degenerate PCR detection in unconventional hosts and environmental samples have elucidated a broader host range, including fish, a diversity of mammals, and invertebrates, for members of the family Circoviridae. Notably, these methods have uncovered a distinct group of viruses that are closely related to members of the genus
\end{abstract}

Electronic supplementary material The online version of this article (doi:10.1007/s00705-017-3247-y) contains supplementary material, which is available to authorized users.

Karyna Rosario

krosari2@mail.usf.edu

Arvind Varsani

arvind.varsani@asu.edu

1 College of Marine Science, University of South Florida, Saint Petersburg, FL 33701, USA

2 Institute for Veterinary Medical Research, Centre for Agricultural Research, Hungarian Academy of Sciences, Budapest, Hungary

3 Departament de Sanitat i Anatomia Animals, Universitat Autònoma de Barcelona, Bellaterra, 08193 Barcelona, Spain

4 UAB, Centre de Recerca en Sanitat Animal (CReSA, IRTAUAB), Campus de la Universitat Autònoma de Barcelona, Bellaterra, 08193 Barcelona, Spain
Circovirus and comprise a new genus, Cyclovirus. The discovery of new viruses and a re-evaluation of genomic features that characterize members of the Circoviridae prompted a revision of the classification criteria used for this family of animal viruses. Here we provide details on an updated Circoviridae taxonomy ratified by the International Committee on the Taxonomy of Viruses in 2016, which establishes the genus Cyclovirus and reassigns the genus Gyrovirus to the family Anelloviridae, a separate lineage of animal viruses that also contains circular ssDNA genomes. In addition, we provide a new species demarcation threshold of $80 \%$ genome-wide pairwise identity for members of the family Circoviridae, based on pairwise identity distribution analysis, and list guidelines to distinguish between members of this family and other eukaryotic viruses with circular, ssDNA genomes.
5 Blood Systems Research Institute, San Francisco, California, USA

6 Department of Laboratory Medicine, University of California, San Francisco, San Francisco, California, USA

7 Viral Emergence and Co-evolution Unit, ADES, UMR 7268, Aix-Marseille University, CNRS, EFS, 27 Bd. Jean Moulin, 13005 Marseille, France

8 The Biodesign Center for Fundamental and Applied Microbiomics, Center for Evolution and Medicine, School of Life sciences, Arizona State University, Tempe, AZ 85287-5001, USA

9 Structural Biology Research Unit, Department of Clinical Laboratory Sciences, University of Cape Town, Observatory, Cape Town, South Africa 


\section{Introduction}

The family Circoviridae was established in the mid-1990s when it was recognized that animal viruses with circular, single-stranded DNA (ssDNA) genomes were distinct from other eukaryotic ssDNA viruses classified at the time, including plant viruses with circular genomes (Geminiviridae) and animal viruses with linear genomes (Parvoviridae) [47, 83]. Originally, all the known animal viruses with covalently closed circular ssDNA genomes were classified in a single genus, Circovirus, within this family [47]. These animal viruses included avian and swine pathogens, namely beak and feather disease virus (BFDV), chicken anemia virus (CAV) and porcine circovirus (PCV, specifically the virus currently known as PCV-1). However, it is now recognized that animal viruses with circular ssDNA genomes are highly diverse and genome structure alone cannot be used for their taxonomical classification.

The last published report from the International Committee on Taxonomy of Viruses (ICTV), the $9^{\text {th }}$ report reflecting the taxonomy from 2009, lists 12 viral species in the family Circoviridae [4]. These species are divided into two genera: Circovirus, which contained 11 species infecting birds and pigs, and Gyrovirus, which only included CAV. However, the progressive identification of new genomic sequences similar to members of the genus Circovirus in various animals and environmental samples subsequent to the release of the $9^{\text {th }}$ report has prompted a revision of the classification framework used for this family. Furthermore, structural and genomic data indicate that CAV may represent a different lineage of ssDNA viruses and, thus, the genus Gyrovirus needed to be removed from the family Circoviridae. The genomic features of CAV are more closely aligned with ssDNA viruses in the family Anelloviridae and, thus, the genus Gyrovirus was reassigned to this family.

In this article we re-visit genomic features that characterize members of the family Circoviridae and provide an update to the taxonomy reported in the ICTV $9^{\text {th }}$ report by: 1) establishing a new genus, Cyclovirus, that accommodates a distinct group of viruses closely related to members of the genus Circovirus; 2) reassigning the genus Gyrovirus to the family Anelloviridae; and 3) redefining the species demarcation criteria for members of the family Circoviridae and implementing a genome-wide pairwise identity based approach to classify known as well as new viruses that have been reported within the past six years.

\section{Conserved genomic features among members of the family Circoviridae}

\section{Genus Circovirus}

Most of what is known about circoviruses, or members of the genus Circovirus, comes from veterinary science-related research since these viruses are responsible for fatal diseases that affect birds (e.g., BFDV) and swine (e.g., PCV-2) [83]. In fact, until 2010, pigs were the only mammals known to be affected by circoviruses and most of the diversity for this group of viruses was reported from avian species (Table 1). However, studies employing viral metagenomic-based strategies and degenerate PCR for circoviruses in unconventional hosts have since identified the presence of circovirus genomes in freshwater fish $[45,46]$ and various mammals, including bats [34-36, 42, 91], chimpanzees [34], dogs [37], humans [34] and minks [41]. Although a definitive host has not been confirmed for some of these newly-detected circoviruses (e.g., bat-associated circoviruses), phylogenetic analyses indicate that circovirus genomes detected in mammals, in general, are more closely-related to each other than to avian circoviruses (Fig. 1).

Circovirus genomes range in size from $\sim 1.8$ to $\sim 2.1 \mathrm{~kb}$ and are packaged within non-enveloped virions that have an icosahedral $\mathrm{T}=1$ structure and have an average diameter of $\sim 15$ - $25 \mathrm{~nm}[10,69,82,83]$. All circovirus genomes have an ambisense organisation containing open reading frames (ORFs) arranged on different strands of a dsDNA replicative form. Two major ORFs (>600 nt), encoding the replicationassociated protein (Rep) on the virion strand and capsid protein $(\mathrm{Cp})$ on the complementary strand of the replicative form, can be readily identified in circovirus genomes [4] (Fig. 2). The Rep, which has sequence motifs characteristic of proteins involved in rolling circle replication (RCR; see below) [28], is the most conserved circovirus protein. On the other hand, the $\mathrm{Cp}$ is significantly divergent and is only characterized by an N-terminal region rich in basic amino acids that may provide DNA binding activity [57]. Although Rep- and Cp-encoding ORFs are present in all circovirus genomes, other proteins may also be expressed by several circovirus species. For example, more than six ORFs have been identified in both avian and porcine circovirus genomes (e.g., [2, 23]) and BFDV virions have been consistently found associated with up to three proteins $[68,69]$. Notably, porcine circoviruses (PCV-1 and PCV-2) are known to encode a third protein, denominated VP3, with apoptotic capacity $[26,32,44]$ as well as a fourth one, ORF4, with a potential anti-apoptotic function [48]. 
Table 1 List of viral species classified within the family Circoviridae

\begin{tabular}{|c|c|c|c|c|c|c|c|}
\hline Genus & Species/virus name & Acronym & $\begin{array}{l}\text { Accession } \\
\#\end{array}$ & $\begin{array}{l}\text { Isolation source } \\
\text { (organism) }\end{array}$ & Isolation source (tissue) & Country & Reference \\
\hline \multirow[t]{27}{*}{ Circovirus } & Barbel circovirus & $\mathrm{BarCV}$ & GU799606 & Barbus barbus & $\begin{array}{l}\text { Whole specimens (Fry } \\
\text { stage) }\end{array}$ & Hungary & {$[45]$} \\
\hline & $\begin{array}{c}\text { Bat associated } \\
\text { circovirus } 1\end{array}$ & BatACV-1 & JX863737 & $\begin{array}{l}\text { Rhinolophus } \\
\text { ferrumequinum }\end{array}$ & Guts & Myanmar & {$[24]$} \\
\hline & $\begin{array}{c}\text { Bat associated } \\
\text { circovirus } 2\end{array}$ & BatACV-2 & KC339249 & $\begin{array}{l}\text { Rhinolophus } \\
\text { ferrumequinum }\end{array}$ & Guts & Myanmar & {$[24]$} \\
\hline & $\begin{array}{c}\text { Bat associated } \\
\text { circovirus } 3\end{array}$ & BatACV-3 & JQ814849 & $\begin{array}{l}\text { Rhinolophus } \\
\text { ferrumequinum }\end{array}$ & $\begin{array}{l}\text { Pharyngeal \& rectal } \\
\text { swabs }\end{array}$ & China & {$[90]$} \\
\hline & $\begin{array}{c}\text { Bat associated } \\
\text { circovirus } 4\end{array}$ & BatACV-4 & KT783484 & Tadarida brasiliensis & Pharyngeal swabs & Brazil & [42] \\
\hline & $\begin{array}{c}\text { Bat associated } \\
\text { circovirus } 5\end{array}$ & BatACV-5 & KJ641727 & Plecotus auritus & $\begin{array}{l}\text { Pharyngeal \& rectal } \\
\text { swabs }\end{array}$ & China & [91] \\
\hline & $\begin{array}{c}\text { Bat associated } \\
\text { circovirus } 6\end{array}$ & BataCV-6 & KJ641724 & Rhinolophus affinis & $\begin{array}{l}\text { Pharyngeal \& rectal } \\
\text { swabs }\end{array}$ & China & [91] \\
\hline & $\begin{array}{c}\text { Bat associated } \\
\text { circovirus } 7\end{array}$ & BatACV-7 & KJ641723 & Rhinolophus sinicus & $\begin{array}{l}\text { Pharyngeal \& rectal } \\
\text { swabs }\end{array}$ & China & [91] \\
\hline & $\begin{array}{c}\text { Bat associated } \\
\text { circovirus } 8\end{array}$ & BatACV-8 & KJ641711 & Myotis ricketti & $\begin{array}{l}\text { Pharyngeal \& rectal } \\
\text { swabs }\end{array}$ & China & [91] \\
\hline & $\begin{array}{l}\text { Beak and feather } \\
\text { disease virus* }\end{array}$ & BFDV & AF071878 & Psittaciformes species & Skin & USA & {$[57]$} \\
\hline & Canary circovirus* & $\mathrm{CaCV}$ & AJ301633 & Serinus canaria & Organs & Italy & [84] \\
\hline & Canine circovirus & CanineCV & KC241982 & Canis lupus familiaris & Liver & USA & {$[37]$} \\
\hline & $\begin{array}{c}\text { Chimpanzee } \\
\text { associated } \\
\text { circovirus } 1\end{array}$ & ChimpACV-1 & GQ404851 & Pan troglodytes & Faeces & Rwanda & [34] \\
\hline & Duck circovirus* & $\mathrm{DuCV}$ & DQ100076 & Anas domesticus & $\begin{array}{l}\text { Liver, spleen, thymus, } \\
\text { \& Bursa fabricii }\end{array}$ & USA & {$[1]$} \\
\hline & $\begin{array}{l}\text { European catfish } \\
\text { circovirus }\end{array}$ & EcatfishCV & JQ011377 & Silurus glanis & $\begin{array}{l}\text { Liver, spleen, gills, } \\
\text { kidneys \& gonads }\end{array}$ & Hungary & [46] \\
\hline & Finch circovirus* & $\mathrm{FiCV}$ & DQ845075 & Chloebia gouldiae & Bursa fabricii & N/A & {$[86]$} \\
\hline & Goose circovirus* & $\mathrm{GoCV}$ & AJ304456 & Goose & Bursa fabricii & Germany & {$[85]$} \\
\hline & Gull circovirus* & $\mathrm{GuCV}$ & DQ845074 & Larus argentatus & Bursa fabricii & Sweden & {$[86]$} \\
\hline & $\begin{array}{l}\text { Human associated } \\
\text { circovirus } 1\end{array}$ & $\mathrm{HuACV}-1$ & GQ404856 & Homo sapiens & Faeces & Nigeria & [34] \\
\hline & Mink circovirus & $\mathrm{MiCV}$ & KJ020099 & Mustela sp. & Gut & China & [41] \\
\hline & Pigeon circovirus* & $\mathrm{PiCV}$ & AF252610 & Columbia livia & Bursa fabricii & Germany & {$[52]$} \\
\hline & Porcine circovirus $1 *$ & PCV-1 & AF071879 & N/A & Cell culture & N/A & {$[57]$} \\
\hline & Porcine circovirus $2 *$ & PCV-2 & AF027217 & Sus domesticus & $\begin{array}{l}\text { Lungs, lymph nodes, } \\
\text { spleens, \& tonsils }\end{array}$ & Canada & {$[23]$} \\
\hline & Raven circovirus* & $\mathrm{RaCV}$ & DQ146997 & Corvus coronoides & Feathers & Australia & [78] \\
\hline & Starling circovirus* & $\mathrm{StCV}$ & DQ172906 & Sturnus vulgaris & Spleen & Spain & [29] \\
\hline & Swan circovirus* & SwCV & EU056309 & Cygnus olor & Liver and spleen & Germany & {$[22]$} \\
\hline & $\begin{array}{r}\text { Zebra finch } \\
\text { circovirus }\end{array}$ & ZfiCV & KP793918 & Taeniopygia guttata & N/A & Germany & {$[67]$} \\
\hline \multirow[t]{4}{*}{ Cyclovirus } & $\begin{array}{c}\text { Bat associated } \\
\text { cyclovirus } 1\end{array}$ & BatACyV-1 & HM228874 & Antrozous pallidus & Faeces & USA & {$[35]$} \\
\hline & $\begin{array}{c}\text { Bat associated } \\
\text { cyclovirus } 2\end{array}$ & BatACyV-2 & JF938079 & Myotis spp. & Faeces & China & {$[18]$} \\
\hline & $\begin{array}{c}\text { Bat associated } \\
\text { cyclovirus } 3\end{array}$ & BatACyV-3 & JF938081 & Myotis spp. & Faeces & China & {$[18]$} \\
\hline & $\begin{array}{c}\text { Bat associated } \\
\text { cyclovirus } 4\end{array}$ & BatACyV-4 & JF938082 & Myotis spp. & Faeces & China & {$[18]$} \\
\hline
\end{tabular}


Table 1 continued

\begin{tabular}{|c|c|c|c|c|c|c|c|}
\hline Genus & Species/virus name & Acronym & $\begin{array}{l}\text { Accession } \\
\#\end{array}$ & $\begin{array}{l}\text { Isolation source } \\
\text { (organism) }\end{array}$ & Isolation source (tissue) & Country & Reference \\
\hline & $\begin{array}{c}\text { Bat associated } \\
\text { cyclovirus } 5\end{array}$ & BatACyV-5 & HQ738637 & Tadarida brasiliensis & Muscle & USA & {$[36]$} \\
\hline & $\begin{array}{c}\text { Bat associated } \\
\text { cyclovirus } 6\end{array}$ & BatACyV-6 & KJ641712 & Rhinolophus pusillus & $\begin{array}{l}\text { Pharyngeal \& rectal } \\
\text { swabs }\end{array}$ & China & [91] \\
\hline & $\begin{array}{c}\text { Bat associated } \\
\text { cyclovirus } 7\end{array}$ & BatACyV-7 & KJ641740 & Rhinolophus pusillus & $\begin{array}{l}\text { Pharyngeal \& rectal } \\
\text { swabs }\end{array}$ & China & [91] \\
\hline & $\begin{array}{c}\text { Bat associated } \\
\text { cyclovirus } 8\end{array}$ & BatACyV-8 & KJ641715 & Rhinolophus pusillus & $\begin{array}{l}\text { Pharyngeal \& rectal } \\
\text { swabs }\end{array}$ & China & [91] \\
\hline & $\begin{array}{c}\text { Bat associated } \\
\text { cyclovirus } 9\end{array}$ & BatACyV-9 & KJ641720 & Tylonycteris pachypus & $\begin{array}{l}\text { Pharyngeal \& rectal } \\
\text { swabs }\end{array}$ & China & [91] \\
\hline & $\begin{array}{l}\text { Bat associated } \\
\text { cyclovirus } 10\end{array}$ & BatACyV-10 & KM382270 & $\begin{array}{l}\text { Molossus molossus, } \\
\text { Tadarida brasiliensis }\end{array}$ & Faeces & Brazil & [43] \\
\hline & $\begin{array}{l}\text { Bat associated } \\
\text { cyclovirus } 11\end{array}$ & BatACyV-11 & KJ641717 & Myotis spp. & $\begin{array}{l}\text { Pharyngeal \& rectal } \\
\text { swabs }\end{array}$ & China & [91] \\
\hline & $\begin{array}{l}\text { Bat associated } \\
\text { cyclovirus } 12\end{array}$ & BatACyV-12 & KM382269 & $\begin{array}{l}\text { Molossus molossus, } \\
\text { Tadarida brasiliensis }\end{array}$ & Faeces & Brazil & {$[43]$} \\
\hline & $\begin{array}{l}\text { Bat associated } \\
\text { cyclovirus } 13\end{array}$ & BatACyV-13 & KJ641728 & Plecotus auritus & $\begin{array}{l}\text { Pharyngeal \& rectal } \\
\text { swabs }\end{array}$ & China & [91] \\
\hline & $\begin{array}{l}\text { Bat associated } \\
\text { cyclovirus } 14\end{array}$ & BatACyV-14 & KT732785 & Pteropus tonganus & Faeces & Tonga & [49] \\
\hline & $\begin{array}{l}\text { Bat associated } \\
\text { cyclovirus } 15\end{array}$ & BatACyV-15 & KT732786 & Pteropus tonganus & Faeces & Tonga & [49] \\
\hline & $\begin{array}{l}\text { Bat associated } \\
\text { cyclovirus } 16\end{array}$ & BatACyV-16 & KT732787 & Pteropus tonganus & Faeces & Tonga & [49] \\
\hline & $\begin{array}{l}\text { Bovine associated } \\
\text { cyclovirus } 1\end{array}$ & BoACyV-1 & HQ738634 & Bos taurus & Muscle & Pakistan & [36] \\
\hline & $\begin{array}{l}\text { Chicken associated } \\
\text { cyclovirus } 1\end{array}$ & $\begin{array}{l}\text { ChickACyV- } \\
1\end{array}$ & HQ738643 & Gallus gallus & Muscle & Nigeria & {$[36]$} \\
\hline & $\begin{array}{l}\text { Chimpanzee } \\
\text { associated } \\
\text { cyclovirus } 1\end{array}$ & $\begin{array}{l}\text { ChimpACyV- } \\
1\end{array}$ & GQ404849 & Pan troglodytes & Faeces & $\begin{array}{l}\text { Central } \\
\text { Africa }\end{array}$ & [34] \\
\hline & $\begin{array}{l}\text { Cockroach associated } \\
\text { cyclovirus } 1\end{array}$ & CroACyV-1 & JX569794 & Eurycotis floridana & Abdomen & USA & [59] \\
\hline & $\begin{array}{l}\text { Dragonfly associated } \\
\text { cyclovirus } 1\end{array}$ & DfACyV-1 & JX185419 & Pantala flavescens & Abdomen & Tonga & {$[70]$} \\
\hline & $\begin{array}{l}\text { Dragonfly associated } \\
\text { cyclovirus } 2\end{array}$ & DfACyV-2 & JX185422 & Pantala flavescens & Abdomen & USA & {$[71]$} \\
\hline & $\begin{array}{l}\text { Dragonfly associated } \\
\text { cyclovirus } 3\end{array}$ & DfACyV-3 & JX185424 & Erythemis simplicicollis & Abdomen & USA & [71] \\
\hline & $\begin{array}{l}\text { Dragonfly associated } \\
\text { cyclovirus } 4\end{array}$ & DfACyV-4 & KC512916 & Aeshna multicolor & Abdomen & USA & {$[11]$} \\
\hline & $\begin{array}{l}\text { Dragonfly associated } \\
\text { cyclovirus } 5\end{array}$ & DfACyV-5 & JX185426 & Erythrodiplax umbrata & Abdomen & $\begin{array}{r}\text { Puerto } \\
\text { Rico }\end{array}$ & [71] \\
\hline & $\begin{array}{l}\text { Dragonfly associated } \\
\text { cyclovirus } 6\end{array}$ & DfACyV-6 & KC512918 & Aeshna multicolor & Abdomen & USA & [11] \\
\hline & $\begin{array}{l}\text { Dragonfly associated } \\
\text { cyclovirus } 7\end{array}$ & DfACyV-7 & KC512919 & $\begin{array}{c}\text { Xanthocnemis } \\
\text { zealandica }\end{array}$ & Abdomen & $\begin{array}{l}\text { New } \\
\text { Zealand }\end{array}$ & [11] \\
\hline & $\begin{array}{l}\text { Dragonfly associated } \\
\text { cyclovirus } 8\end{array}$ & DfACyV-8 & KC512920 & Orthetrum Sabina & Abdomen & Australia & [11] \\
\hline & $\begin{array}{l}\text { Feline associated } \\
\text { cyclovirus } 1\end{array}$ & $\mathrm{FeACyV}-1$ & KM017740 & Felis catus & Faeces & USA & [92] \\
\hline & $\begin{array}{l}\text { Goat associated } \\
\text { cyclovirus } 1\end{array}$ & GoACyV-1 & HQ738636 & Capra aegagrus hircus & Muscle & Pakistan & [36] \\
\hline
\end{tabular}


Table 1 continued

\begin{tabular}{|c|c|c|c|c|c|c|c|}
\hline Genus & Species/virus name & Acronym & $\begin{array}{l}\text { Accession } \\
\#\end{array}$ & $\begin{array}{l}\text { Isolation source } \\
\text { (organism) }\end{array}$ & Isolation source (tissue) & Country & Reference \\
\hline & $\begin{array}{l}\text { Horse associated } \\
\text { cyclovirus } 1\end{array}$ & HoACyV-1 & KR902499 & Equus caballus & Nasal secretions & USA & {$[38]$} \\
\hline & $\begin{array}{l}\text { Human associated } \\
\text { cyclovirus } 1\end{array}$ & HuACyV-1 & GQ404847 & Homo sapiens & Faeces & Pakistan & {$[34]$} \\
\hline & $\begin{array}{l}\text { Human associated } \\
\text { cyclovirus } 2\end{array}$ & $\mathrm{HuACyV}-2$ & GQ404844 & Homo sapiens & Faeces & Pakistan & {$[34]$} \\
\hline & $\begin{array}{l}\text { Human associated } \\
\text { cyclovirus } 3\end{array}$ & HuACyV-3 & GQ404846 & Homo sapiens & Faeces & Pakistan & {$[34]$} \\
\hline & $\begin{array}{l}\text { Human associated } \\
\text { cyclovirus } 4\end{array}$ & $\mathrm{HuACyV}-4$ & GQ404857 & Homo sapiens & Faeces & Tunisia & {$[34]$} \\
\hline & $\begin{array}{l}\text { Human associated } \\
\text { cyclovirus } 5\end{array}$ & HuACyV-5 & GQ404845 & Homo sapiens & Faeces & Pakistan & {$[34]$} \\
\hline & $\begin{array}{l}\text { Human associated } \\
\text { cyclovirus } 6\end{array}$ & HuACyV-6 & GQ404854 & Homo sapiens & Faeces & Nigeria & {$[34]$} \\
\hline & $\begin{array}{l}\text { Human associated } \\
\text { cyclovirus } 7\end{array}$ & $\mathrm{HuACyV-7}$ & GQ404855 & Homo sapiens & Faeces & Nigeria & {$[34]$} \\
\hline & $\begin{array}{l}\text { Human associated } \\
\text { cyclovirus } 8\end{array}$ & $\mathrm{HuACyV}-8$ & KF031466 & Homo sapiens & Cerebrospinal fluid & Vietnam & {$[80]$} \\
\hline & $\begin{array}{l}\text { Human associated } \\
\text { cyclovirus } 9\end{array}$ & HuACyV-9 & KC771281 & Homo sapiens & Blood serum & Malawi & {$[76]$} \\
\hline & $\begin{array}{l}\text { Human associated } \\
\text { cyclovirus } 10\end{array}$ & HuACyV-10 & KF726984 & Homo sapiens & Respiratory secretion & Chile & {$[63]$} \\
\hline & $\begin{array}{l}\text { Human associated } \\
\text { cyclovirus } 11\end{array}$ & HuACyV-11 & KJ831064 & Homo sapiens & Cerebrospinal fluid & Sri Lanka & {$[64]$} \\
\hline & $\begin{array}{l}\text { Squirrel associated } \\
\text { cyclovirus } 1\end{array}$ & SqACyV-1 & LC018134 & $\begin{array}{l}\text { Callosciurus erythraeus } \\
\text { thaiwanensis }\end{array}$ & Stomach contents & Japan & [73] \\
\hline
\end{tabular}

Viral species described before 2010 are marked with an asterisk

N/A = information not available

The presence of a well-conserved Rep in circovirus genomes suggests that these viruses replicate through RCR and recombinant expression studies support this idea [7, 16, 51, 77]. Circovirus Reps are characterized by the presence of three RCR motifs at the N-terminus including, motif I [FT(L/I)NN], motif II [PHLQG] and motif III [YC(S/x)K] where " $\mathrm{x}$ " represents any residue [72] (Fig. 3). In addition to the RCR domain, circovirus Reps contain dNTP-binding or P-loop NTPase domains characteristic of superfamily 3 (SF3) helicases which are distinguished by the presence of three conserved motifs tightly packed in a domain containing $\sim 100$ amino acids $[19,20]$. The SF3 helicase motifs found in circovirus Reps include Walker-A [G(P/x)(P/x)GxGK(S/t)], Walker-B [uuDDF], and motif $\mathrm{C}[\mathrm{UTSN}]$ where " $\mathrm{x}$ " represents any residue, "u" represents a hydrophobic amino acid (i.e., F, I, L, V, M), and residues in lower case are observed at lower frequency [72].

In addition to conserved gene synteny and the presence of a Rep with characteristic RCR and helicase motifs, circovirus genomes have two intergenic regions (IR) and a conserved origin of replication (ori) (Fig. 2). The ori is located within the IR located between the $5^{\prime}$ ends of the Rep- and Cp-encoding ORFs [50]. The circovirus ori is characterized by a conserved nonanucleotide motif ' $(\mathrm{T} /$ n)A(G/t)TATTAC' (Fig. 2), where lower case nucleotides are observed at low frequency and ' $n$ ' represents any nucleotide, located at the apex of a potential stem-loop structure $[50,72]$. The Rep introduces a nick in the virionsense strand between positions 7 and 8 of the nonanucleotide motif (i.e., TAGTATT ${ }^{\downarrow}$ AC), presumably initiating circovirus genome replication through RCR [77].

\section{Genus Cyclovirus, a newly established taxon}

In 2010, a group of viruses most-closely related to circoviruses were discovered through viral metagenomic analysis and degenerate PCR in stool samples from primates (humans and chimpanzees) and meat products from various animals (camels, chickens, cows, goats, and sheep) [34]. These viruses were tentatively named cycloviruses to distinguish them from the already known circoviruses, 


\section{Circovirus}
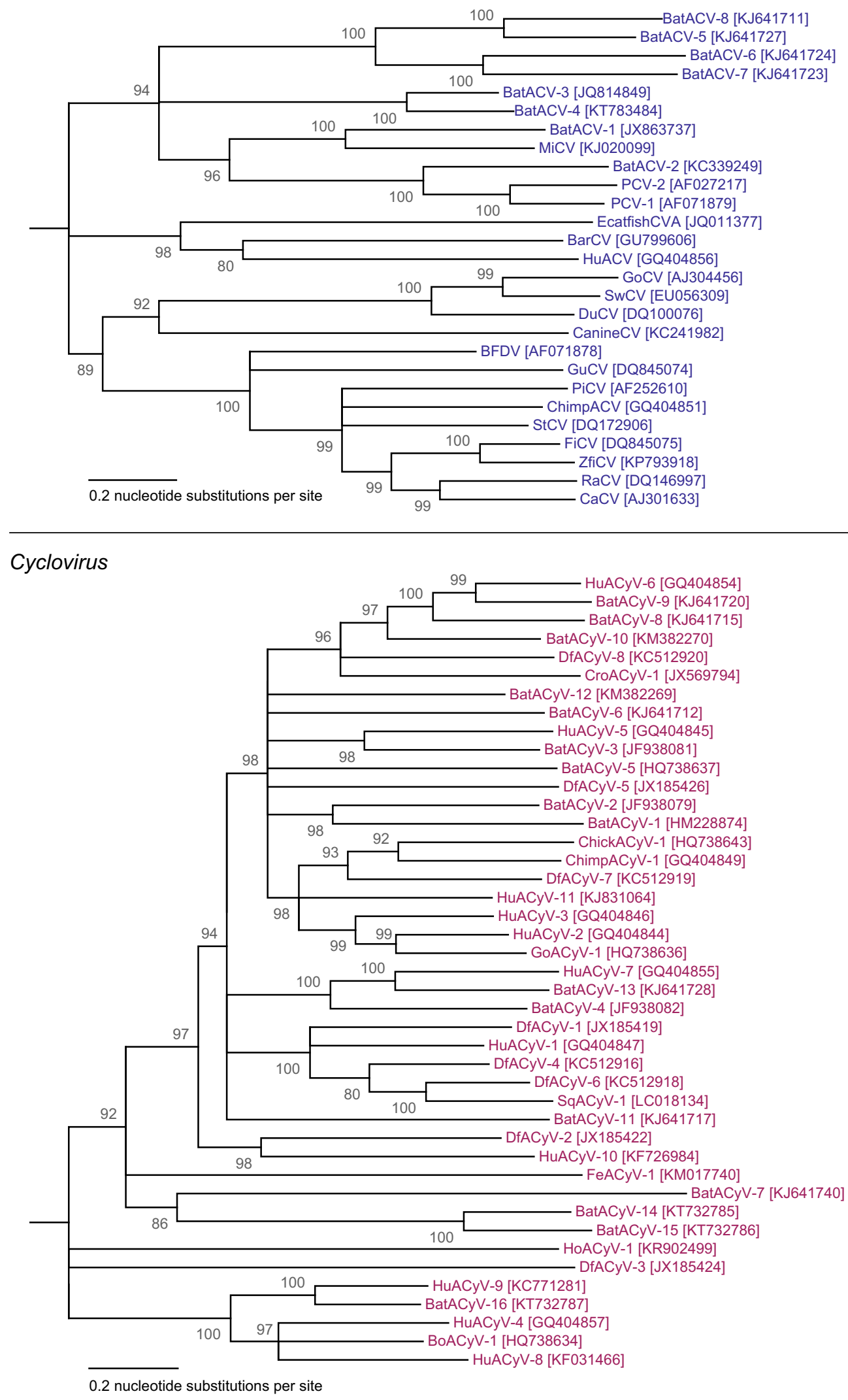
४Fig. 1 Maximum likelihood (ML) phylogenetic trees of representative sequences from members of viral species within the genus Circovirus (top) and the genus Cyclovirus (bottom). The ML trees were inferred using PhyML [21] with the GTR $+\mathrm{G}$ model of substitution after aligning complete genome sequences using the MUSCLE algorithm [15]. Branches with $<80 \%$ SH-like support have been collapsed. The phylogenetic trees of circoviruses and cycloviruses were rooted after using cyclovirus or circovirus reverse complemented genome sequences as an outgroup, respectively. Species acronyms are defined in Table 1

while still highlighting the circular topology of their genomes [34]. Cycloviruses are closely related to circoviruses and share genomic features with this well-known group of animal pathogens [14]. However, phylogenetic and genomic differences between circoviruses and cycloviruses

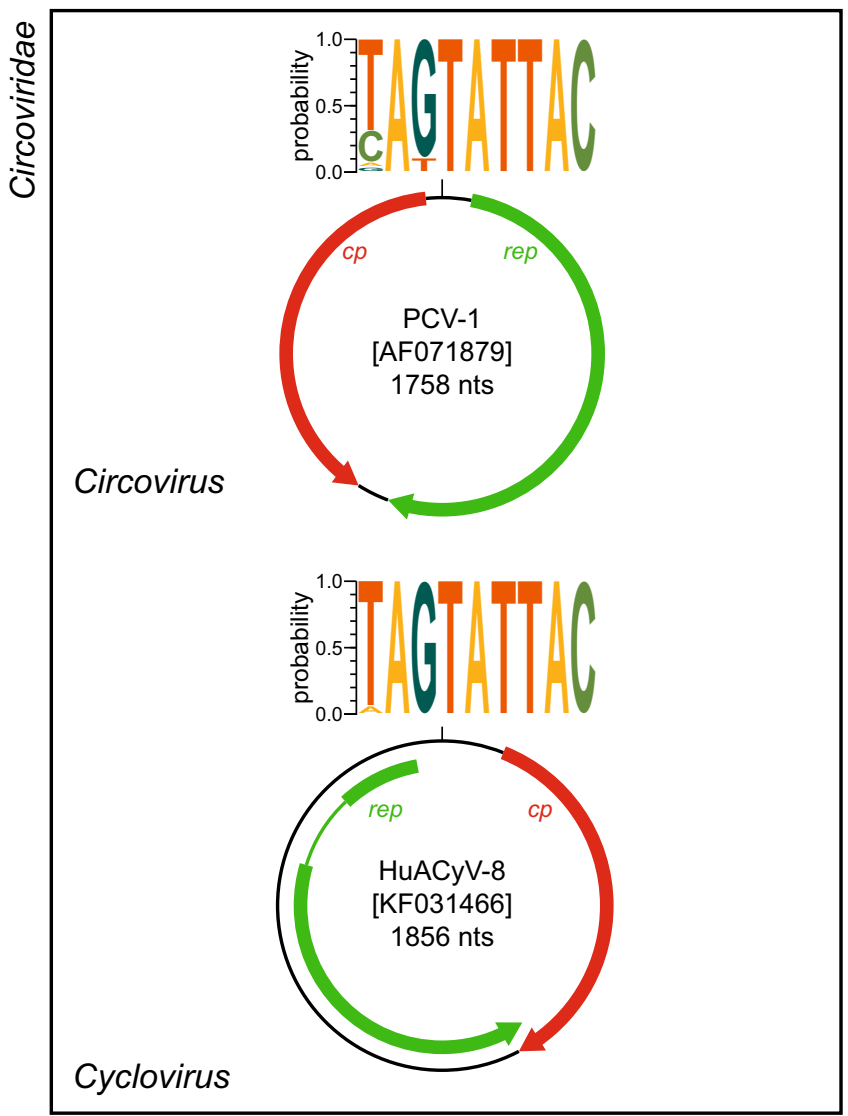

Fig. 2 Genome schematics illustrate the major open reading frames (ORFs) characteristic of members of the Circoviridae (left) and Anelloviridae families (right). Members of the family Circoviridae, including the Circovirus and Cyclovirus genera, have two major ORFs encoding replication-associated (Rep) and capsid ( $\mathrm{Cp}$ ) proteins as well as a conserved nonanucleotide motif marking the origin of replication. The nonanucleotide motif sequence is depicted through sequence probability logos generated in Weblogo 3 [9]. Note that the orientation of major ORFs relative to the nonanucleotide motif differs between genomes representing the Circovirus and Cyclovirus genera. The rep of the Cyclovirus type species, Human associated cyclovirus 8 ( $\mathrm{HuACyV}-8)$, is interrupted by an intron. Although the presence of justified the creation of a second taxonomic unit, the newly established genus Cyclovirus, within the family Circoviridae.

In contrast to circoviruses, cycloviruses have been found associated with both vertebrates and invertebrates. Although cycloviruses were discovered in stool samples from primates [34], cyclovirus genomes have now been reported from a diversity of specimens including mammals (bats, cats, cows, goats, horses, squirrels, sheep) [18, 34, 36, 38, 43, 49, 73, 91, 92], birds (chickens) $[34,36]$, and insects (cockroaches and dragonflies) [11, 59, 70, 71] (Table 1). Additionally, a diversity of cyclovirus genomes have been recovered from human samples other than faeces $[17,34,80]$, including cerebrospinal fluid [80], blood serum [76], and respiratory

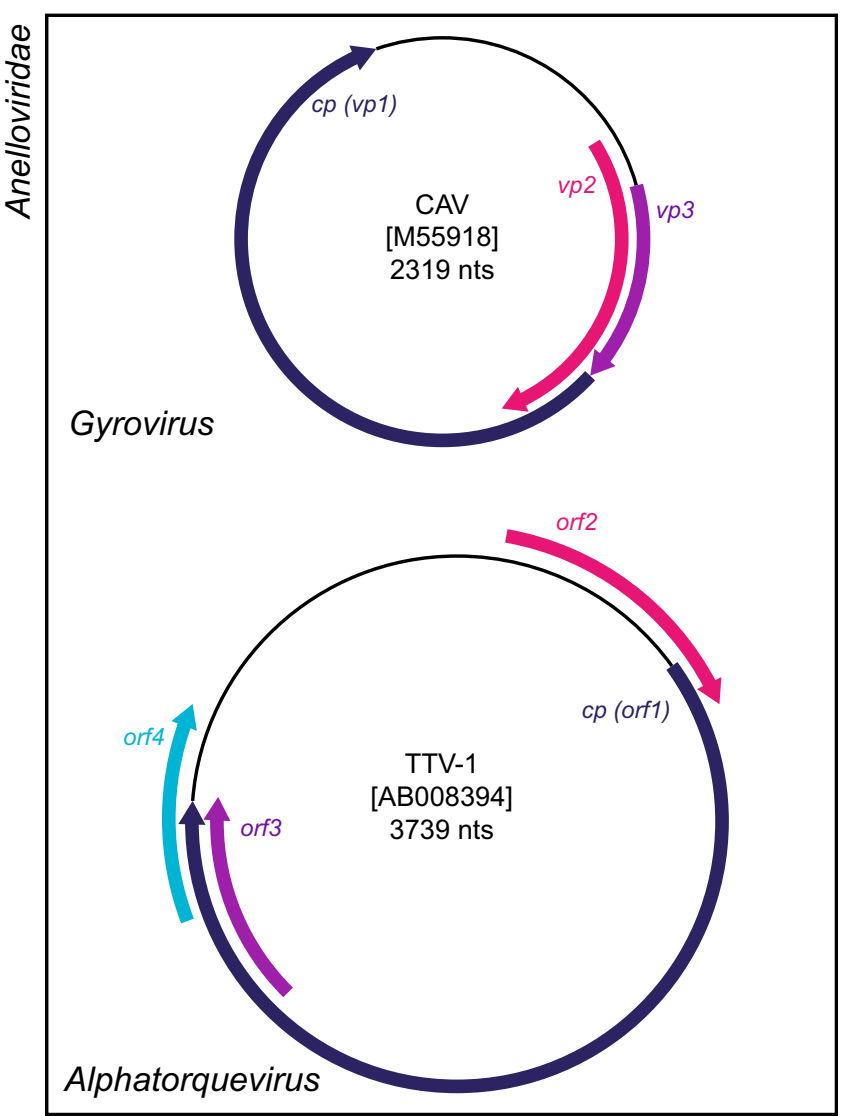

introns has been observed in various cyclovirus genomes, this has not been reported for circoviruses (Supplemental Figures 1 and 2). In contrast to the Circoviridae, members of the family Anelloviridae consistently have three major ORFs in an unisense organization. The genera Gyrovirus, which currently includes Chicken anemia virus (CAV) alone, and Alphatorquevirus, with Torque teno virus 1 (TTV1) as the type species, are shown to highlight similarities among these ssDNA viruses. The CAV-VP1 and TTV-1 ORF1 are thought to represent capsid proteins. Proteins labelled as VP2 and ORF2 in CAV and TTV-1 genome schematics, respectively, contain a motif characteristic of protein tyrosine phosphatases. In addition, the CAV-VP3 and TTV-1 ORF3 proteins exhibit apoptotic activity 


\section{Circoviridae}
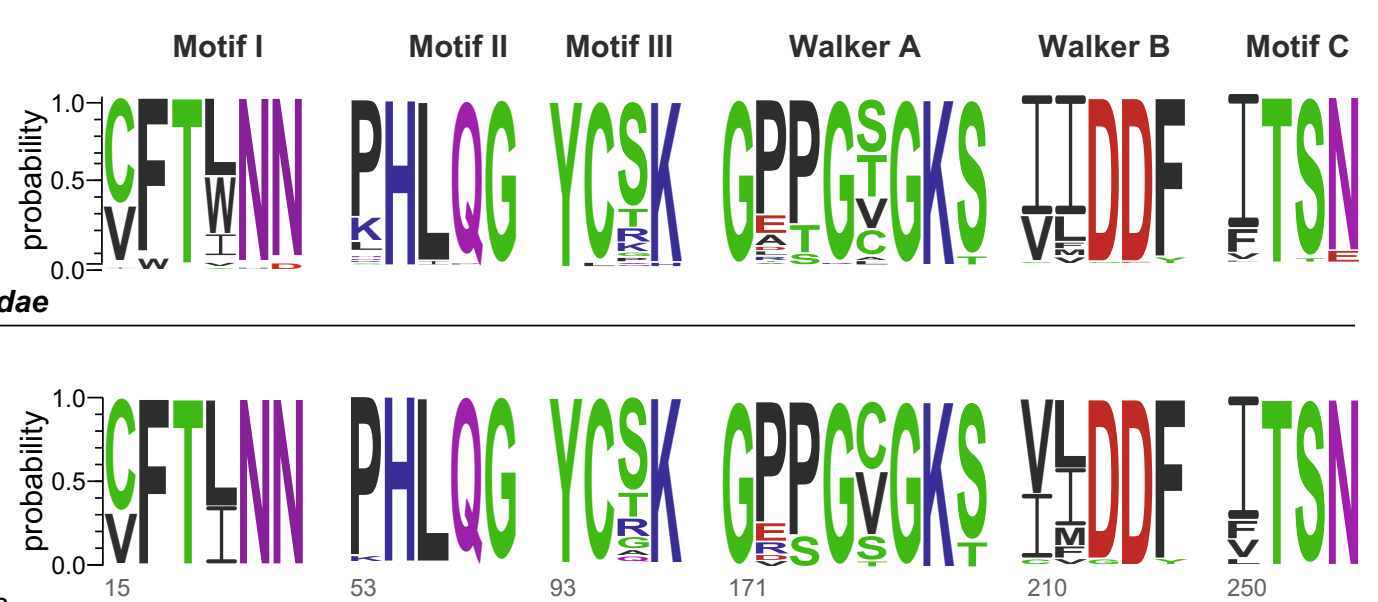

Circovirus
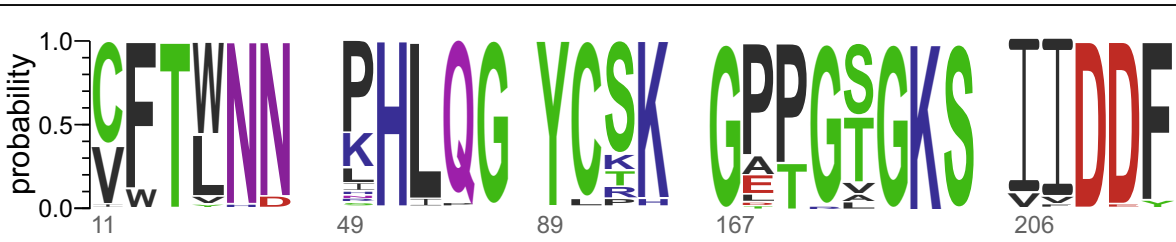

250

Residues

Polar

Neutral

Basic

Acidic

Hydrophobic

Cyclovirus

49

89

167

206

of the 70 species in the family Circoviridae (Circovirus, $\mathrm{n}=27$; Cyclovirus, $\mathrm{n}=43$ ). Numbers below Circovirus and Cyclovirus logos indicate the relative amino acid position for each motif based on the type species, including Porcine circovirus 1 (accession number AF071879) and Human associated cyclovirus 8 (accession number KF031466), respectively

secretions [63]. However, it has been difficult to identify a definitive host for most, if not all, cycloviruses since these viruses have only been identified through metagenomic analysis and degenerate PCR. This is further complicated by the fact that many cycloviruses have been discovered from guts and fecal samples (Table 1), which may include viruses that are dietary in origin. Moreover, phylogenetic analysis of cyclovirus genomes did not reveal any clusters by the type of organism from which they were identified (Fig. 1).

Similar to circoviruses, cycloviruses have small genomes $(\sim 1.7$ to $1.9 \mathrm{~kb})$ that contain two major ORFs encoding the Rep and Cp organized in two different strands of a dsDNA form (Fig. 2) [34, 72]. Both Rep and Cp of cycloviruses have similar features when compared with their corresponding circovirus proteins (reviewed by $[14,72])$. The cyclovirus Rep contains motifs similar to circovirus RCR and SF3 helicase motifs, including RCR motifs I [FT(L/W)NN], II [(P/x)HLQG] and III [Y(C/l)(S/ $\mathrm{x}) \mathrm{K}]$ and SF3 helicase motifs Walker-A $[\mathrm{G}(\mathrm{P} / \mathrm{x})(\mathrm{P} / \mathrm{t})(\mathrm{G} /$ $\mathrm{x}) \mathrm{xGKS}$ ], Walker-B [uuDDF], and motif $\mathrm{C}$ [uTS(N/e)] where " $x$ " represents any type of residue and " $u$ " represents a hydrophobic amino acid (i.e., F, I, L, V, M). The

cyclovirus putative $\mathrm{Cp}$ is also characterized by an N-terminal region rich in basic amino acids as seen in circovirus Cps. Furthermore, the putative cyclovirus ori is marked by the same conserved nonamer observed in circoviruses ('TAGTATTAC') located at the apex of a potential stemloop structure (Fig. 2) [72].

Despite these similarities, phylogenetic analyses of the Rep and Cp show that circoviruses and cycloviruses form distinct clades (Fig. 4). Furthermore, there are key genomic features that distinguish cycloviruses from circoviruses (Fig. 2). Cyclovirus genomes contain an IR between the $5^{\prime}$ ends of Rep- and Cp-encoding ORFs; however, the IR between the $3^{\prime}$ ends of these major ORFs is either absent or consistently smaller than that observed in circovirus genomes [34, 72]. Additionally, cycloviruses and circoviruses might employ slightly different replication and transcription strategies since their genome coding regions are organized differently. Although the cyclovirus virion strand has not been empirically determined, it is predicted that these viruses encapsidate the strand containing the conserved nonanucleotide motif based on what has been shown for other eukaryotic Rep-encoding, ssDNA viruses [72]. Using the nonanucleotide motif as a point of 


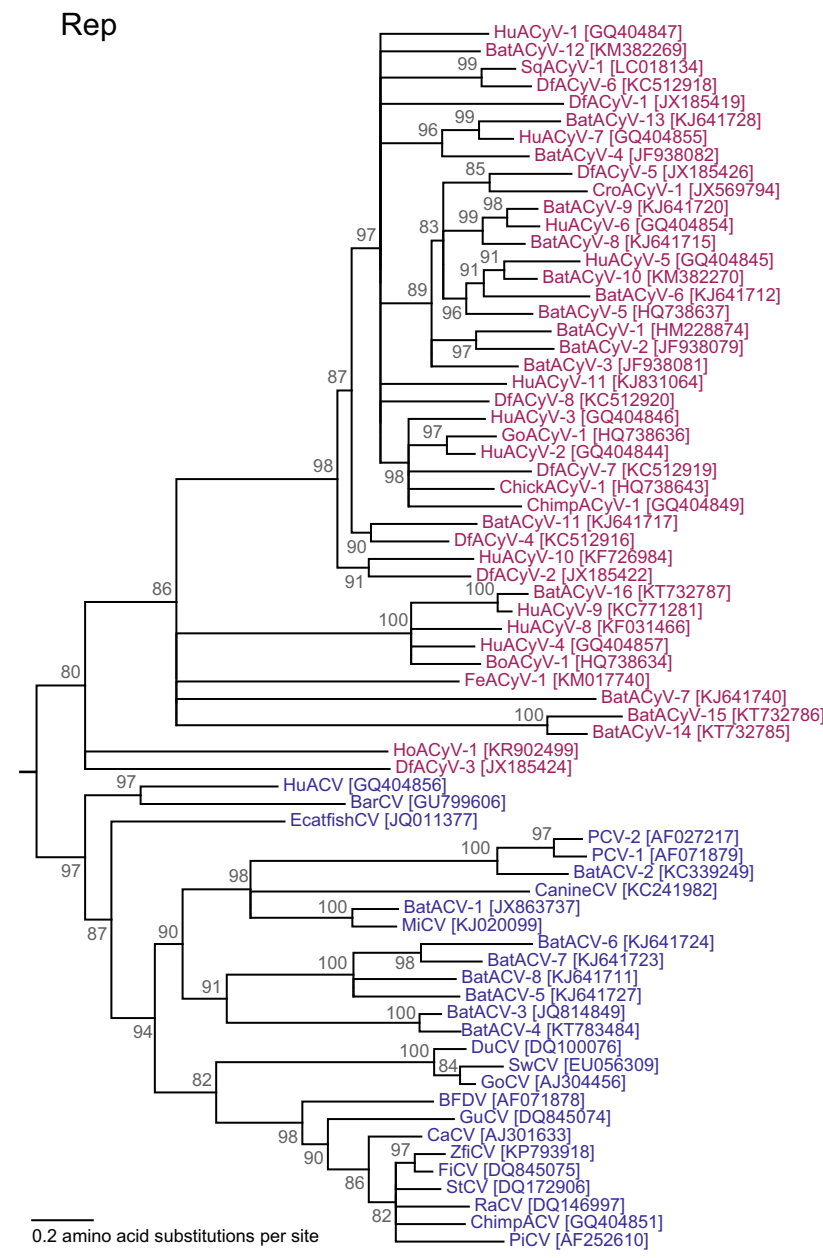

Fig. 4 Maximum likelihood (ML) phylogenetic trees of representative replication-associated protein (Rep; left) rooted with Reps of closely related sequences (GenBank accession \#s JX904473, $\mathrm{KC} 248418$ and KJ547623) and mid-point rooted capsid protein (Cp; right) amino acid sequences of representatives from viral species

reference, it is clear that the genome organization of cycloviruses seems to be a mirror image from the one seen in circoviruses. The putative ori, which is marked by the nonanucleotide motif, is located on the Rep-encoding strand of circoviruses, while in cycloviruses is located on the Cp-encoding strand [72]. In addition to differences in genomic arrangement, the presence of introns has been identified within the ORFs of several cyclovirus genomes, whereas this has not been reported for circoviruses (Supplemental Figures 1 and 2).

\section{Reassignment of the genus Gyrovirus to the family Anelloviridae}

Since CAV, BFDV, and PCV were the first described animal viruses with circular ssDNA genomes, studies sought to better understand the relationship between these

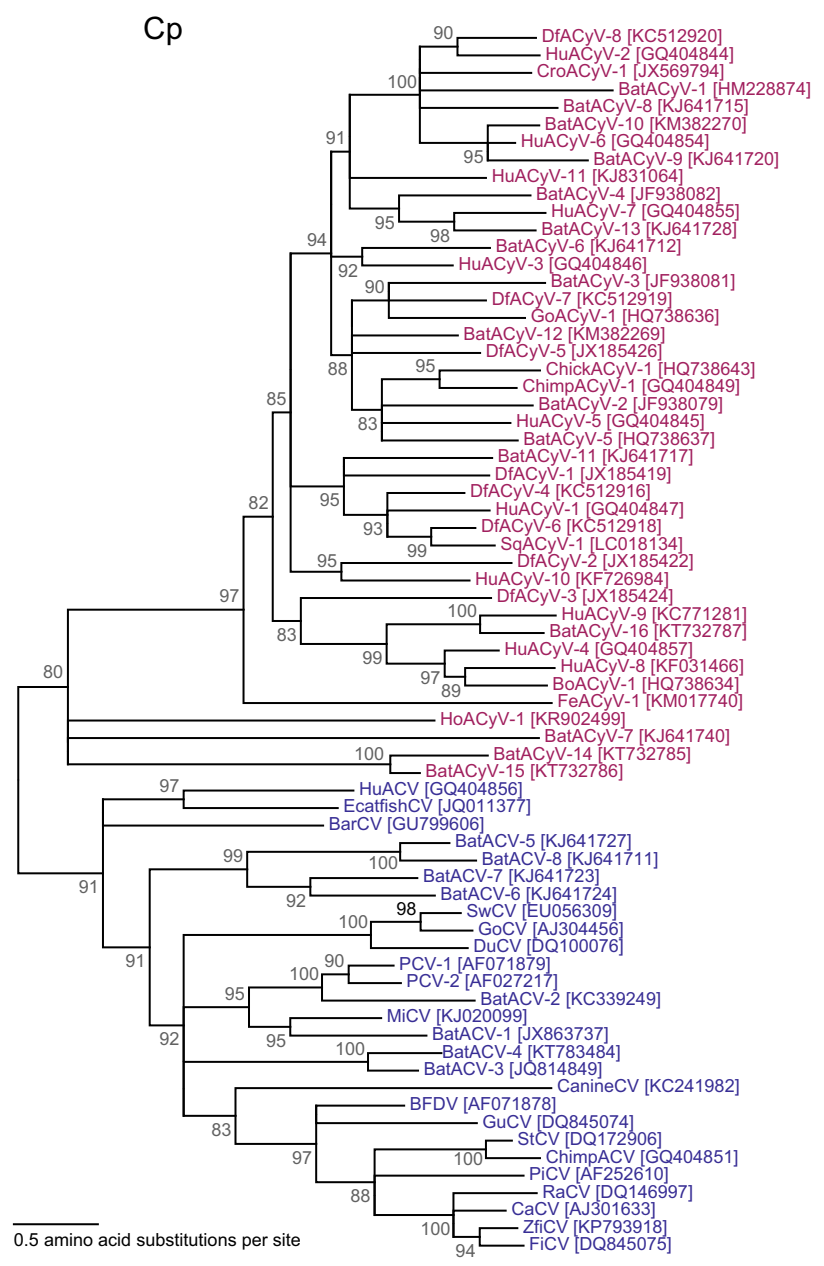

within the Circovirus (blue font) and Cyclovirus (purple font) genera. The ML trees were inferred using PhyML [21] with the LG model of substitution after aligning amino acid sequences using the MUSCLE algorithm [15]. Branches with $<80 \%$ SH-like support have been collapsed. Species acronyms are defined in Table 1

three viruses. As early as 1991 it was noted that CAV virions had marked physicochemical and morphological differences when compared to BFDV and PCV, which were indistinguishable under the same conditions [82]. Therefore, even before animal viruses with circular ssDNA genomes were classified, it was 'inadvisable' to place CAV in the same family as BFDV and PCV based on comparative electron microscopy [82]. Despite these observations, CAV became the type species of the family Circoviridae when it was originally reported as an official virus family in 1995 with the release of the ICTV $6^{\text {th }}$ Report [47]. Nevertheless, early on it was recognized that CAV did not share the same characteristics as BFDV and PCV and thus a second genus, Gyrovirus, was created within the family Circoviridae in 1999 to accommodate CAV [27]. The genus Gyrovirus, with CAV as its sole member, remained in the family for more than a decade. However, mounting genomic, molecular, and structural data indicated that CAV 
represents a different lineage of ssDNA viruses as originally suspected, thus granting the placement of the genus Gyrovirus in a separate family.

Although CAV virions are non-enveloped and icosahedral, they are larger than circovirus virions and have a unique structure with protruding pentagonal shaped units compared to flat pentameric units observed in circoviruses $[10,82]$. In addition to appearing structurally unrelated to circoviruses, CAV has a genomic architecture that is radically different from that of circoviruses. The CAV genome has a negative-sense organization, containing three major overlapping ORFs in the virion or genomic strand $[31,58]$ (Fig. 2). Moreover, CAV genomes do not encode an identifiable Rep and lack the conserved nonanucleotide motif that marks the ori of circoviruses and cycloviruses $[53,57,72]$.

Gyroviruses do not appear to be either structurally or genetically related to members of the family Circoviridae. Instead, the genomic features of CAV are reminiscent of members of the family Anelloviridae (Fig. 2). The family Anelloviridae, which accommodates 12 genera of vertebrate-infecting viruses, currently represents the only other family of animal viruses with covalently closed, circular ssDNA genomes [5]. Although sequence variability within anelloviruses is extremely high, both at the nucleotide and amino acid levels, their genomes have common features [3]. It is important to note that the common genomic features that justified the creation of the family Anelloviridae [3] are also observed in CAV genomes. Similar to CAV, anellovirus genomes have a negative-sense organization with overlapping ORFs with similar relative sizes $[3,12,54,79]$. In addition, anellovirus and CAV genomes contain GC-rich stretches in non-coding regions where replication is thought to initiate due to the presence of potential stem-loop structures $[2,13]$. The non-coding or untranslated region of CAV and some anellovirus genomes also contains similar regulatory elements and share high identity within a 36-nt stretch [25, 54]. Moreover, CAV and some anelloviruses have similar transcription patterns $[25,30]$.

Although CAV and anelloviruses do not have significant sequence similarities, these viruses may encode proteins with similar functions. The largest ORF observed in CAV and anellovirus genomes encodes for a putative structural protein, named VP1 and ORF1, respectively. Both VP1 and ORF1 are characterized by an $\mathrm{N}$-terminal region rich in basic amino acids, which resembles Cps encoded by members of the family Circoviridae [3, 57]. Biochemical characterization of CAV virions revealed VP1 as the sole Cp component for this gyrovirus [81]; however, this has not been conclusively demonstrated for the anellovirus ORF1. CAV and anellovirus genomes also have two other ORFs that encode proteins with similar characteristics and are of comparable sizes. The VP2 and ORF2 of CAV and anellovirus genomes, respectively, encode a protein containing a motif characteristic of protein tyrosine phosphatases (i.e., $\mathrm{WX}_{7} \mathrm{HX}_{3} \mathrm{CXCX}_{5} \mathrm{H}$, where ' $\mathrm{X}$ ' represents any residue) [60]. In addition, the CAV-VP3 and ORF3 of some anelloviruses encode a protein with comparable apoptotic capacity [33, 65].

Based on similarities in genome architectures and transcription profiles, gyroviruses are more closely related to members of the family Anelloviridae rather than to those of the Circoviridae. Therefore, the genus Gyrovirus has been reassigned to the former family. Until 2011, CAV was the only described gyrovirus species. However, other potential members of the genus Gyrovirus have been recently discovered in humans and birds. These novel gyroviruses (GyVs) have been identified in human skin (human gyrovirus (HGyV) [74]) and feces (GyV3 through GyV6; $[8,61,62]$ ), chicken serum (avian gyrovirus 2 (AGV2) [66]) and meat (GyV4 and GyV7; [8]) as well as spleen and uropygial gland tissues from sea birds (GyV8; [39]). Since HGyV and AGV2 may represent the same species [61], the genus Gyrovirus should soon be updated to reflect at least eight viral species.

\section{Revised species demarcation criteria for the family Circoviridae}

The ICTV $9^{\text {th }}$ Report specified a species demarcation criteria for members of the family Circoviridae (i.e., genus Circovirus) of $<75 \%$ genome-wide identity and $<70 \%$ amino acid identity for the $\mathrm{Cp}$ [4]. However, these criteria were based on the distribution of pairwise identities derived from global alignments which may be inaccurate due to inconsistencies introduced during alignment and gap-handling issues [55]. Furthermore, the above mentioned species demarcation criteria did not include members of the newly established genus Cyclovirus and circovirus-related genomes that have been reported since 2009. Therefore, there is a need to re-evaluate the species demarcation criteria for members of the family Circoviridae. Here we use a pairwise identity distribution analysis to establish species demarcation criteria to classify viruses within the family Circoviridae.

Pairwise identities derived from aligning pairs of genome sequences individually have been recently used as a more standardized and accurate method to calculate genome identity scores $[55,56]$. Hence, we reanalyzed and calculated genome-wide pairwise identities for all the circovirus and cyclovirus genomes available in public databases through June 2016 using SDT v1.2 [56] (Supplemental Figures 3 and 4; Supplemental File 1). The analysis shows that a pairwise identity species cut-off 
between $78 \%-80 \%$ is best suited for both circoviruses and cycloviruses (Fig. 5). Since PCV-1 and PCV-2 share 79\% genome-wide pairwise identity (Supplemental Figure 3) and these viruses have been historically considered to represent separate species due to marked biological differences (i.e., pathogenicity), we have delineated the species demarcation threshold at $80 \%$. Therefore, the newly established species demarcation criteria will maintain the current classification for all previously characterized circovirus species, including the closely-related PCV-1 and PCV-2. The $80 \%$ genome-wide pairwise identity cut-off is well supported phylogenetically for both circoviruses and cycloviruses (Fig. 1). As a general rule, viruses that have $<80 \%$ genome-wide pairwise identities with other members of the family Circoviridae coupled with phylogenetic support should be considered distinct species.

The $80 \%$ identity threshold for distinct species generally holds true for pairwise comparisons of either the $c p$ or rep gene sequences (Fig. 5). However, only complete genomes

Cyclovirus
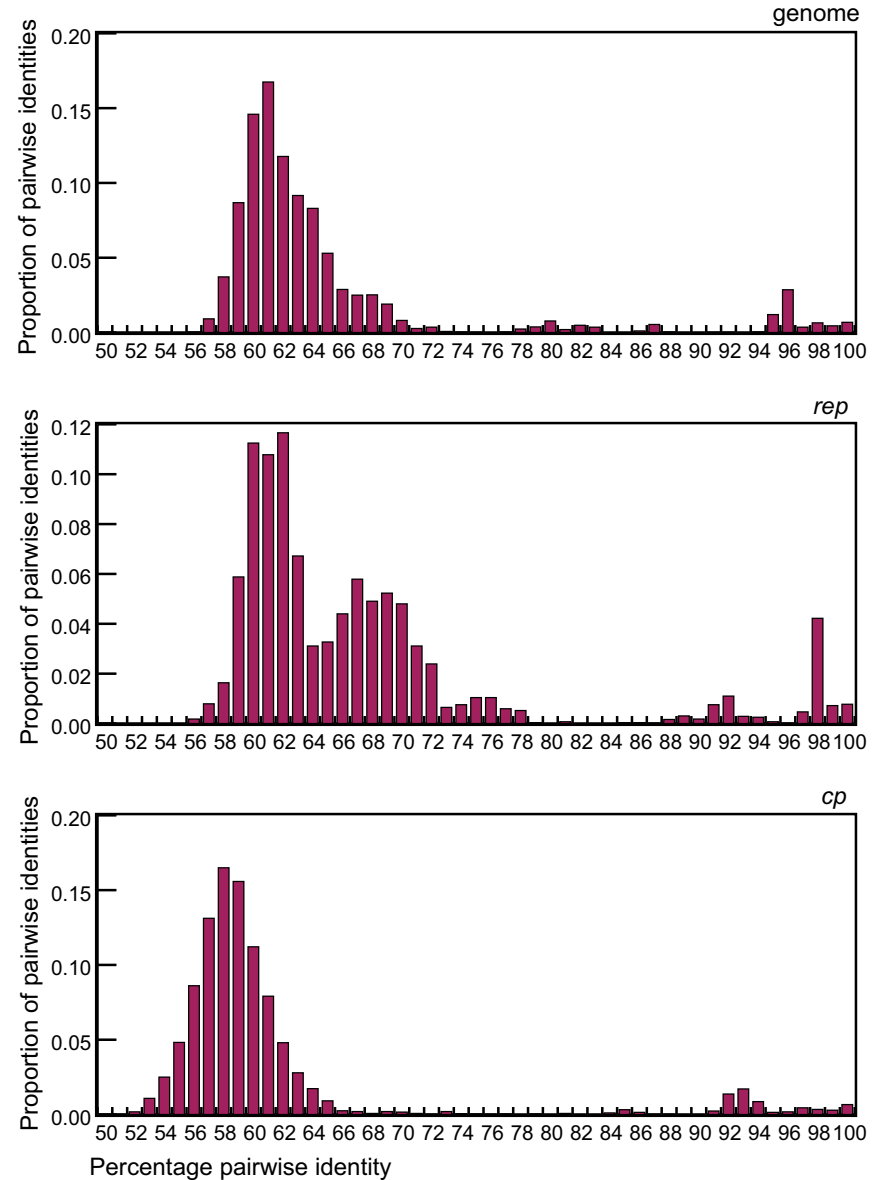

Fig. 5 Distribution of pairwise identities among members of the genus Cyclovirus (purple bars; left) and the genus Circovirus (blue bars; right). Plots reflect pairwise identities based on calculations for complete genome sequences (top) as well as the replication- should be considered for assignment of new species in the event that they share $<80 \%$ pairwise identity with any classified species within the family Circoviridae. Notably, pairwise comparisons between circoviruses and cycloviruses indicate that members of the family Circoviridae can have overlapping pairwise identity ranges based on the Rep. Cyclovirus Reps may share up to $50 \%$ amino acid pairwise identity with those of some circoviruses, which is higher than pairwise identities observed among cycloviruses (as low as 36\%) and circoviruses (as low as 40\%) alone (Supplemental Figure 5). Therefore, the classification of newly identified viruses with significant similarities to either circoviruses or cycloviruses should be primarily based on genomic characteristics and genome-wide pairwise identities. Rep identities and genome organization (specifically the location of the ori relative to coding regions) should be used to identify a genome as belonging to either the Circovirus or Cyclovirus genus. Once this distinction is made, circovirus and cyclovirus nucleotide

\section{Circovirus}
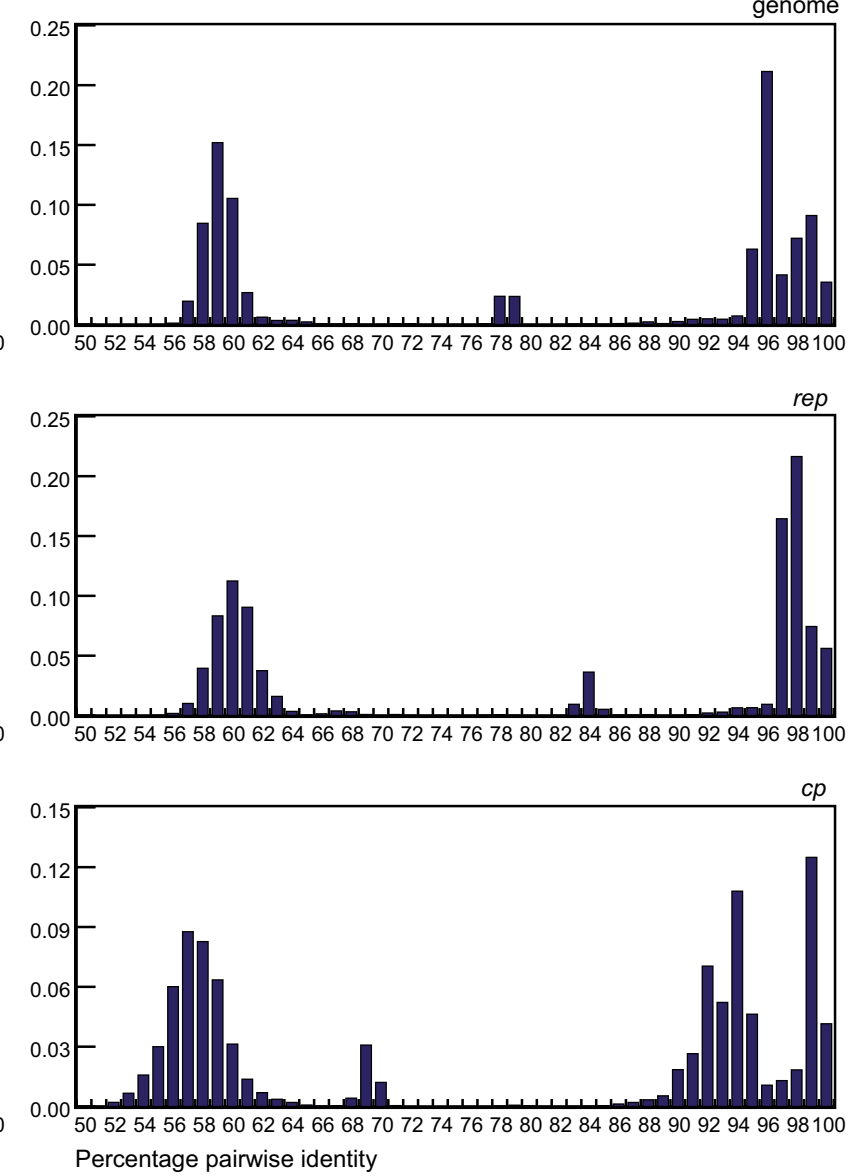

associated (rep; middle) and capsid ( $c p$; bottom) genes. All pairwise identities were calculated using the Sequence Demarcation Tool version 1.2 [56] with the MUSCLE alignment algorithm [15] 
sequences should be analysed independently for pairwise identity comparisons and taxonomic classification. Otherwise, obtaining a reliable alignment of complete genome sequences is extremely difficult since cycloviruses and circoviruses have a different genome organization. Even if cyclovirus genomes could be aligned to circoviruses to some degree by reverse complementing cyclovirus sequences, such an approach is not recommended since the $\mathrm{Cp}$ is highly divergent compared to the Rep.

After determining that $80 \%$ genome-wide pairwise identity was a suitable threshold for species demarcation, we classified all of the Circoviridae-related genomes available in GenBank through the end of June 2016 (Table 1). Note that the original published names for many of the genomes have been changed for consistency and that viruses for which a definitive host has not been identified are denoted by the presence of the word 'associated' in the species name. The latest analysis indicates that there are 27 distinct circovirus species. PCV-2 is, by far, the species with the most reported genome sequences, followed by BFDV, reflecting the interest in these animal pathogens over the years (Fig. 6). After the ICTV ratification of circovirus species listed here, a third porcine circovirus species, named PCV-3, was discovered [40]. The PCV-3 genome sequence was not included in the analyses presented in this taxonomy update; however, preliminary analyses indicate that indeed PCV-3 represents a new circovirus species. Although cycloviruses were discovered more recently than circoviruses, there are twice as many species $(n=43)$ reported to date that belong to the $C y$ clovirus genus than there are species from the genus Circovirus. It is possible that cycloviruses are more diverse and widespread than circoviruses since the former have been reported from both vertebrate and invertebrate animals, whereas circovirus genomes have only been found associated with birds, freshwater fish, and mammals.

\section{Recommendations for classifying Circoviridae sequences}

As more metagenomic analyses are performed on a diversity of organisms and environments, it is expected that novel circoviruses and cycloviruses will continue to be identified. In an effort to standardize the taxonomy framework for the family Circoviridae, here we outline a few guidelines regarding how to analyse and report genomes representing members of this family.

1) Genome sequence verification. ICTV will now consider classifying viral species based on complete genome sequences derived from metagenomic analyses [75]. Since the genomes of members of the
Fig. 6 Diversity of variants within each assigned species in the Circovirus (blue font) and Cyclovirus (purple font) genera. The total number of isolates within the species is given in parentheses by each species name. Details regarding genome sequences used for this analysis are provided in Supplementary File 1

family Circoviridae are relatively small $(\sim 2 \mathrm{~kb})$ and have a circular topology, efforts should be made to close genomes and, whenever possible, verify genomes through inverse PCR. One of the biggest limitations of metagenomically-derived genomes is that there are no isolates of the viruses being described. Amplifying complete genomes through inverse PCR and cloning before sequencing will provide a biological archive of described viral genomes within plasmids. Additionally, working with PCR-verified genomes will ensure that the reported sequences are not chimeric entities assembled from metagenomic data.

2) Submitting sequences to GenBank. It is important to provide the correct annotation for major proteins (Rep and $\mathrm{Cp}$ ) when submitting genome sequences to GenBank, including the identification and removal of introns. In addition, for consistency, all genomes should be submitted starting with the first nucleotide of the nonanucleotide motif. This will ensure that the genomes are reported in the correct orientation, which is a key feature for distinguishing between circovirus and cyclovirus genomes. All species level representative sequences analysed for this manuscript have been provided as supplemental material following the format indicated above, including complete genomes (Supplemental Files 2A and 2B) as well as Rep (Supplemental Files 3A and 3B) and $\mathrm{Cp}$ (Supplemental Files 4A and 4B) coding sequences.

3) Naming species. The following basic rules should be implemented when naming viral species:

a. If a given genome has $>80 \%$ genome-wide pairwise identity with a genome sequence from a member of a previously described viral species, the name from the existing species should be adopted and a specific isolate name should be provided. For example, a newly identified virus in foxes that has a genome-wide pairwise identity of $>80 \%$ with sequences from members of the species Canine circovirus could be named 'Canine circovirus [fox-associated isolate 1]'.

b. If a novel virus representing a new species is being described (i.e., the genome has $<80 \%$ genome-wide pairwise identity with known viral sequences) the word 'associated' should be added as a modifier to the species name, unless 
Barbel circovirus ( $n=2)$

Bat associated circovirus 1 ( $n=1)$

Bat associated circovirus $2(n=1)$

Bat associated circovirus $3(n=1)$

Bat associated circovirus $4(n=1)$

Bat associated circovirus $5(n=1)$

Bat associated circovirus $6(n=1)$

Bat associated circovirus $7(n=1)$

Bat associated circovirus $8(n=1)$

Beak and feather disease virus $(n=371)$

Canary circovirus $(n=1)$

Canine circovirus ( $n=29)$

Chimpanzee associated circovirus ( $n=1)$

Duck circovirus ( $n=110$ )

European catfish circovirus ( $n=2)$

Finch circovirus ( $n=1)$

Goose circovirus ( $n=42$ )

Gull circovirus $(n=5)$

Human associated circovirus $1(n=1)$

Mink circovirus $(n=1)$

Pigeon circovirus $(n=48)$

Porcine circovirus $1(n=56)$

Porcine circovirus 2 ( $n=1640)$

Raven circovirus ( $n=1)$

Starling circovirus $(n=3)$

Swan circovirus $(n=2)$

Zebra finch circovirus ( $n=6$ )

Bat associated cyclovirus $1(n=1)$

Bat associated cyclovirus $2(n=1)$

Bat associated cyclovirus $3(n=1)$

Bat associated cyclovirus $4(n=1)$

Bat associated cyclovirus $5(n=1)$

Bat associated cyclovirus $6(n=1)$

Bat associated cyclovirus $7(n=2)$

Bat associated cyclovirus $8(n=2)$

Bat associated cyclovirus $9(n=1)$

Bat associated cyclovirus $10(n=1)$

Bat associated cyclovirus $11(n=1)$

Bat associated cyclovirus $12(n=1)$

Bat associated cyclovirus $13(n=1)$

Bat associated cyclovirus $14(n=1)$

Bat associated cyclovirus $15(n=1)$

Bat associated cyclovirus $16(n=3)$

Bovine associated cyclovirus $1(n=2)$

Feline associated cyclovirus $1(n=1)$

Chicken associated cyclovirus $1(n=2)$

Chimpanzee associated cyclovirus $1 \quad(n=2)$

Dragonfly associated cyclovirus $1(n=24)$

Dragonfly associated cyclovirus $2(n=2)$

Dragonfly associated cyclovirus $3(n=1)$

Dragonfly associated cyclovirus $4(n=6)$

Dragonfly associated cyclovirus $5(n=2)$

Dragonfly associated cyclovirus $6(n=1)$

Dragonfly associated cyclovirus $7(n=1)$

Dragonfly associated cyclovirus $8(n=1)$

Cockroach associated cyclovirus $1 \quad(n=1)$

Goat associated cyclovirus $1(n=1)$

Horse associated cyclovirus $1(n=1)$

Human associated cyclovirus $1(n=1)$

Human associated cyclovirus $2(n=1)$

Human associated cyclovirus $3(n=2)$

Human associated cyclovirus $4(n=2)$

Human associated cyclovirus $5(n=1)$

Human associated cyclovirus $6(n=1)$

Human associated cyclovirus $7(n=1)$

Human associated cyclovirus $8(n=21)$

Human associated cyclovirus $9(n=1)$

Human associated cyclovirus $10(n=4)$

Human associated cyclovirus $11(n=2)$

Squirrel associated cyclovirus $1(n=1)$
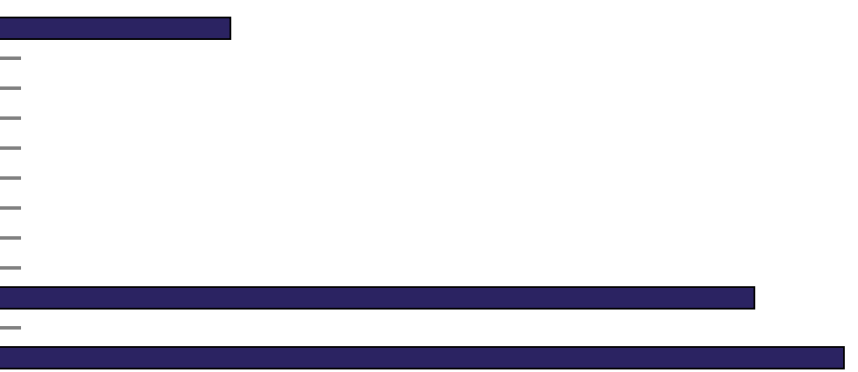

$-$

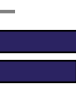

\section{$-$}

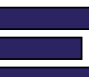

-
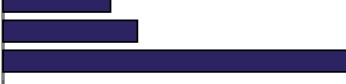

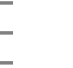
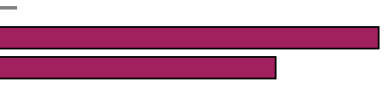

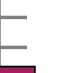

$$
\text { . }
$$

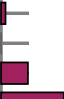

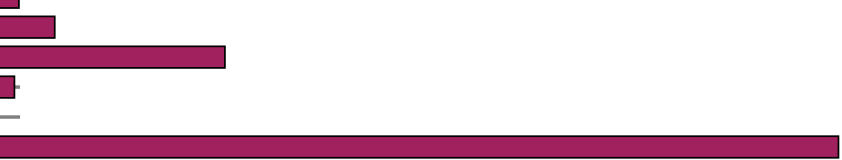

\section{$-$ \\ .}

$$
\text { = }
$$$$
\text { - }
$$

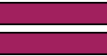

\section{$-$}

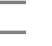
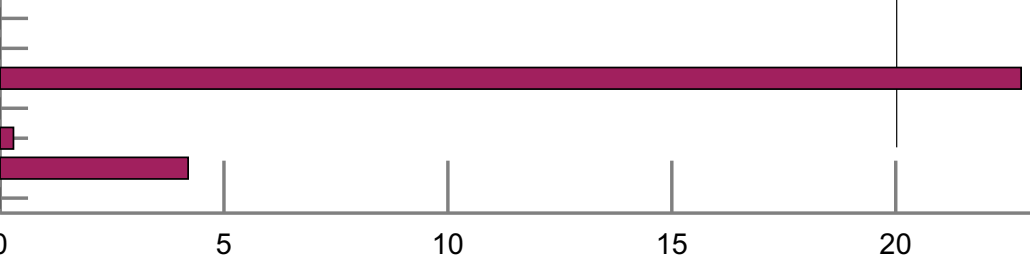

5

5

Percentage diversity 
there is biological data identifying a definitive host (e.g., Bat associated cyclovirus \# species).

4) Resolving species assignment conflicts. There might be instances when it is difficult to classify a new sequence based on the established species demarcation criteria. Here we provide guidelines on how to approach conflicts based on recommendations for classifying species from the family Geminiviridae, another group of Rep-encoding circular, ssDNA viruses $[6,55,87,88]$. Species assignments might be uncertain when:

a. A given sequence shares $>80 \%$ genome-wide pairwise identity with viral sequences within a particular species, but $<80 \%$ identity with other isolates of that same species. This will lead to more than $20 \%$ sequence divergence among variants of a single species (e.g., HuACyV-8, see Fig. 6). To resolve this conflict, the new sequence should be classified within any species with which it shares $>80 \%$ identity based on a given classified isolate, even if it is $<80 \%$ identical to other isolates within that species.

b. A given sequence shares $>80 \%$ genome-wide pairwise identity with viral sequences assigned to two or more different species. In such cases, it is suggested that the new sequence be considered as belonging to the species with which it shares the highest degree of similarity.

5) Reporting non-Circoviridae genomes. A growing number of circular Rep-encoding ssDNA (CRESS DNA) viruses have been reported from various organisms and environments [14, 72] and it is expected that more genomes will continue to be reported. Many of these novel CRESS DNA genome sequences have similarities with members of the family Circoviridae based on the Rep. It is important to note that only sequences that clearly represent members of the Circovirus or Cyclovirus genera, based on genome features discussed here, should be classified as part of the family Circoviridae. If novel sequences with best matches to circovirus or cyclovirus genomes in GenBank share $<55 \%$ genome-wide pairwise identity (Supplemental Figures 3 - 4) with those sequences, they should be considered as unclassified CRESS DNA viral sequences for the time being. Although additional genera in the family Circoviridae may be created in the future, this level of diversity (i.e., $45 \%$ divergence) is similar to the diversity that has been observed in other CRESS DNA viral families, such as the Geminiviridae and Genomoviridae [89].

\section{Concluding remarks}

The growing number of genomes representing members of the family Circoviridae in the database required a reevaluation of the taxonomy classification framework for this family. Here we have reviewed genomic features that characterize members of the family Circoviridae, outlined guidelines on how to analyse genome sequences, and provided a current list of circovirus and cyclovirus species based on the newly established species demarcation criteria. These efforts should facilitate future analyses geared towards elucidating evolutionary relationships among classified as well as newly identified members of the family Circoviridae.

Acknowledgements $\mathrm{KR}$ and $\mathrm{MB}$ are supported by the National Science Foundation's Assembling the Tree of Life Program Grant DEB-1239976.

\section{Compliance with ethical standards}

There are no conflicts of interest; the research did not involve human participants or animals. The data used for the analyses in this manuscript is publicly available in GenBank.

Disclaimer This article is based on the taxonomic proposals 2016.007a,bD.A.v2.Circovirus_5sp and 2016.008a,bD.A.v2.Cyclovirus_15sp which has been considered and approved by the Executive Committee (EC) of the ICTV. AV and BH are elected members of the ICTV EC. KR, MB, JS and ED are current members of the Circoviridae study group of ICTV, whereas PB is a past member of the Circoviridae-Anelloviridae group.

\section{References}

1. Banda A, Galloway-Haskins RI, Sandhu TS, Schat KA (2007) Genetic analysis of a duck circovirus detected in commercial Pekin ducks in New York. Avian Dis 51:90-95

2. Bassami MR, Berryman D, Wilcox GE, Raidal SR (1998) Psittacine beak and feather disease virus nucleotide sequence analysis and its relationship to porcine circovirus, plant circoviruses, and chicken anemia virus. Virology 249:453-459

3. Biagini P (2009) Classification of TTV and related viruses (anelloviruses). In: de Villiers E-M, Hausen Hz (eds) TT viruses: the still elusive human pathogens. Springer, Berlin, pp 21-33

4. Biagini P, Bendinelli M, Hino S, Kakkola L, Mankertz A, Niel C, Okamoto H, Raidal S, Teo CG, Todd D (2012) Family Circoviridae. In: King AMQ, Adams MJ, Carstens EB, Lefkowitz EJ (eds) Virus taxonomy: classification and nomenclature of viruses: ninth report of the International Committee on Taxonomy of Viruses. Academic Press, London, pp 343-349

5. Biagini P, Bendinelli M, Hino S, Kakkola L, Mankertz A, Niel C, Okamoto H, Raidal S, Teo CG, Todd D (2012) Family Anelloviridae. In: King AMQ, Adams MJ, Carstens EB, Lefkowitz EJ (eds) Virus taxonomy: classification and nomenclature of viruses: ninth report of the International Committee on Taxonomy of Viruses. Academic Press, London, pp 331-341 
6. Brown J, Zerbini FM, Navas-Castillo J, Moriones E, RamosSobrinho R, Silva JF, Fiallo-Olivé E, Briddon R, HernándezZepeda C, Idris A, Malathi VG, Martin D, Rivera-Bustamante R, Ueda S, Varsani A (2015) Revision of Begomovirus taxonomy based on pairwise sequence comparisons. Arch Virol 160:1593-1619

7. Cheung AK (2006) Rolling-circle replication of an animal circovirus genome in a theta-replicating bacterial plasmid in Escherichia coli. J Virol 80:8686-8694

8. Chu DKW, Poon LLM, Chiu SSS, Chan KH, Ng EM, Bauer I, Cheung TK, Ng IHY, Guan Y, Wang D, Peiris JSM (2012) Characterization of a novel gyrovirus in human stool and chicken meat. J Clin Virol 55:209-213

9. Crooks GE, Hon G, Chandonia JM, Brenner SE (2004) WebLogo: a sequence logo generator. Genome Res 14:1188-1190

10. Crowther RA, Berriman JA, Curran WL, Allan GM, Todd D (2003) Comparison of the structures of three circoviruses: chicken anemia virus, Porcine circovirus type 2, and Beak and feather disease virus. Vet Res Commun 77:13036-13041

11. Dayaram A, Potter KA, Moline AB, Rosenstein DD, Marinov M, Thomas JE, Breitbart M, Rosario K, Arguello-Astorga GR, Varsani A (2013) High global diversity of cycloviruses amongst dragonflies. J Gen Virol 94:1827-1840

12. de Villiers E-M, zur Hausen H (2009) TT viruses: the still elusive human pathogens. Springer, Berlin

13. de Villiers EM, Borkosky SS, Kimmel R, Gunst K, Fei JW (2011) The diversity of torque teno viruses: In vitro replication leads to the formation of additional replication-competent subviral molecules. J Virol 85:7284-7295

14. Delwart E, Li L (2012) Rapidly expanding genetic diversity and host range of the Circoviridae viral family and other Rep encoding small circular ssDNA genomes. Virus Res 164:114-121

15. Edgar RC (2004) MUSCLE: multiple sequence alignment with high accuracy and high throughput. Nucleic Acids Res 32:1792-1797

16. Faurez F, Dory D, Grasland B, Jestin A (2009) Replication of porcine circoviruses. Virol J 6:60

17. Garigliany M-M, Hagen RM, Frickmann H, May J, Schwarz NG, Perse A, Jöst H, Börstler J, Shahhosseini N, Desmecht D, Mbunkah HA, Daniel AM, Kingsley MT, de Mendonca Campos R, de Paula VS, Randriamampionona N, Poppert S, Tannich E, Rakotozandrindrainy R, Cadar D, Schmidt-Chanasit J (2014) Cyclovirus CyCV-VN species distribution is not limited to Vietnam and extends to Africa. Sci Rep 4:7552

18. Ge XY, Li JL, Peng C, Wu LJ, Yang XL, Wu YQ, Zhang YZ, Shi ZL (2011) Genetic diversity of novel circular ssDNA viruses in bats in China. J Gen Virol 92:2646-2653

19. Gorbalenya AE, Koonin EV, Wolf YI (1990) A new superfamily of putative NTP-binding domains encoded by genomes of small DNA and RNA viruses. FEBS Lett 262:145-148

20. Gorbalenya AE, Koonin EV (1993) Helicases: amino acid sequence comparisons and structure-function relationships. Curr Opin Struc Biol 3:419-429

21. Guindon S, Dufayard J-F, Lefort V, Anisimova M, Hordijk W, Gascuel O (2010) New algorithms and methods to estimate maximum-likelihood phylogenies: Assessing the performance of PhyML 3.0. Syst Biol 59:307-321

22. Halami MY, Nieper H, Müller H, Johne R (2008) Detection of a novel circovirus in mute swans (Cygnus olor) by using nested broad-spectrum PCR. Virus Res 132:208-212

23. Hamel AL, Lin LL, Nayar GP (1998) Nucleotide sequence of porcine circovirus associated with postweaning multisystemic wasting syndrome in pigs. J Virol 72:5262-5267

24. He B, Li Z, Yang F, Zheng J, Feng Y, Guo H, Li Y, Wang Y, Su N, Zhang F, Fan Q, Tu C (2013) Virome profiling of bats from
Myanmar by metagenomic analysis of tissue samples reveals more novel mammalian viruses. PLoS One 8:e61950

25. Hino S, Prasetyo AA (2009) Relationship of torque teno virus to chicken anemia virus. In: de Villiers E-M, Hausen Hz (eds) TT viruses: the still elusive human pathogens. Springer, Berlin, pp 117-130

26. Hough KP, Rogers AM, Zelic M, Paris M, Heilman DW (2015) Transformed cell-specific induction of apoptosis by Porcine circovirus type 1 viral protein 3. J Gen Virol 96:351-359

27. ICTV (2015) Taxonomy release history. International Committee on Taxonomy of Viruses

28. Ilyina TV, Koonin EV (1992) Conserved sequence motifs in the initiator proteins for rolling circle DNA replication encoded by diverse replicons from eubacteria, eucaryotes and archaebacteria. Nucleic Acids Res 20:3279-3285

29. Johne R, Fernandez-de-Luco D, Hofle U, Muller H (2006) Genome of a novel circovirus of starlings, amplified by multiply primed rolling-circle amplification. J Gen Virol 87:1189-1195

30. Kamada K, Kuroishi A, Kamahora T, Kabat P, Yamaguchi S, Hino S (2006) Spliced mRNAs detected during the life cycle of Chicken anemia virus. J Gen Virol 87:2227-2233

31. Kato A, Fujino M, Nakamura T, Ishihama A, Otaki Y (1995) Gene organization of Chicken anemia virus. Virology 209:480-488

32. Kiupel M, Stevenson GW, Galbreath EJ, North A, HogenEsch H, Mittal SK (2005) Porcine circovirus type 2 (PCV2) causes apoptosis in experimentally inoculated BALB/c mice. BMC Vet Res 1:1-8

33. Kooistra K, Zhang YH, Henriquez NV, Weiss B, Mumberg D, Noteborn MH (2004) TT virus-derived apoptosis-inducing protein induces apoptosis preferentially in hepatocellular carcinomaderived cells. J Gen Virol 85:1445-1450

34. Li L, Kapoor A, Slikas B, Bamidele OS, Wang C, Shaukat S, Masroor MA, Wilson ML, Ndjango J-BN, Peeters M, GrossCamp ND, Muller MN, Hahn BH, Wolfe ND, Triki H, Bartkus J, Zaidi SZ, Delwart E (2010) Multiple diverse circoviruses infect farm animals and are commonly found in human and chimpanzee feces. J Virol 84:1674-1682

35. Li L, Victoria JG, Wang C, Jones M, Fellers GM, Kunz TH, Delwart E (2010) Bat guano virome: predominance of dietary viruses from insects and plants plus novel mammalian viruses. J Virol 84:6955-6965

36. Li L, Shan TL, Soji OB, Alam MM, Kunz TH, Zaidi SZ, Delwart E (2011) Possible cross-species transmission of circoviruses and cycloviruses among farm animals. J Gen Virol 92:768-772

37. Li L, McGraw S, Zhu K, Leutenegger CM, Marks SL, Kubiski S, Gaffney P, Dela Cruz FN Jr., Wang C, Delwart E, Pesavento PA (2013) Circovirus in tissues of dogs with vasculitis and hemorrhage. Emerg Infect Dis 19:534-541

38. Li L, Giannitti F, Low J, Keyes C, Ullmann LS, Deng X, Aleman M, Pesavento PA, Pusterla N, Delwart E (2015) Exploring the virome of diseased horses. J Gen Virol 96:2721-2733

39. Li L, Pesavento PA, Gaynor AM, Duerr RS, Phan TG, Zhang W, Deng X, Delwart E (2015) A gyrovirus infecting a sea bird. Arch Virol 160:2105-2109

40. Li Z, He W, Lan Y, Zhao K, Lv X, Lu H, Ding N, Zhang J, Shi J, Shan C, Gao F (2016) The evidence of porcine hemagglutinating encephalomyelitis virus induced nonsuppurative encephalitis as the cause of death in piglets. Peer J 4:e2443

41. Lian H, Liu Y, Li N, Wang Y, Zhang S, Hu R (2014) Novel circovirus from mink, China. Emerg Infect Dis 20:1548-1550

42. Lima FE, Cibulski SP, Dall Bello AG, Mayer FQ, Witt AA, Roehe PM, d'Azevedo PA (2015) A novel chiropteran circovirus genome recovered from a Brazilian insectivorous bat species. Genome Announc 3:e01393-15

43. Lima FE, Cibulski SP, Dos Santos HF, Teixeira TF, Varela AP, Roehe PM, Delwart E, Franco AC (2015) Genomic 
characterization of novel circular ssDNA viruses from insectivorous bats in Southern Brazil. PLoS One 10:e0118070

44. Liu J, Chen I, Kwang J (2005) Characterization of a previously unidentified viral protein in porcine circovirus type 2-infected cells and its role in virus-induced apoptosis. J Virol 79:8262-8274

45. Lőrincz M, Csáagola A, Farkas SL, Széekely C, Tuboly T (2011) First detection and analysis of a fish circovirus. J Gen Virol 92:1817-1821

46. Lőrincz M, Dáan A, Láang M, Csaba G, Tóoth AG, Széekely C, Csáagola A, Tuboly T (2012) Novel circovirus in European catfish (Silurus glanis). Arch Virol 157:1173-1176

47. Lukert PD, de Boer GF, Dale JL, Keese P, McNulty MS, Randles JW, Tischer I (1995) Family Circoviridae. In: Murphy FA, Fauquet CM, Bishop DHL, Ghabrial SA, Jarvis AW, Martelli GP, Mayo MA, Summers MD (eds) Virus taxonomy classification and nomenclature of viruses sixth report of the International Committee on Taxonomy of Viruses. Springer, New York, pp $166-168$

48. Lv Q, Guo K, Zhang G, Zhang Y (2016) The ORF4 protein of porcine circovirus type 2 antagonizes apoptosis by stabilizing the concentration of ferritin heavy chain through physical interaction. J Gen Virol 97:1636-1646

49. Male MF, Kraberger S, Stainton D, Kami V, Varsani A (2016) Cycloviruses, gemycircularviruses and other novel replicationassociated protein encoding circular viruses in Pacific flying fox (Pteropus tonganus) faeces. Infect Genet Evol 39:279-292

50. Mankertz A, Persson F, Mankertz J, Blaess G, Buhk HJ (1997) Mapping and characterization of the origin of DNA replication of porcine circovirus. J Virol 71:2562-2566

51. Mankertz A, Mankertz J, Wolf K, Buhk HJ (1998) Identification of a protein essential for replication of porcine circovirus. J Gen Virol 79:381-384

52. Mankertz A, Hattermann K, Ehlers B, Soike D (2000) Cloning and sequencing of columbid circovirus ( $\mathrm{CoCV}$ ), a new circovirus from pigeons. Arch Virol 145:2469-2479

53. Meehan BM, Creelan JL, McNulty MS, Todd D (1997) Sequence of porcine circovirus DNA: affinities with plant circoviruses. J Gen Virol 78:221-227

54. Miyata H, Tsunoda H, Kazi A, Yamada A, Khan MA, Murakami J, Kamahora T, Shiraki K, Hino S (1999) Identification of a novel GC-rich 113-nucleotide region to complete the circular, singlestranded DNA genome of TT virus, the first human circovirus. J Virol 73:3582-3586

55. Muhire B, Martin DP, Brown JK, Navas-Castillo J, Moriones E, Zerbini FM, Rivera-Bustamante R, Malathi VG, Briddon RW, Varsani A (2013) A genome-wide pairwise-identity-based proposal for the classification of viruses in the genus Mastrevirus (family Geminiviridae). Arch Virol 158:1411-1424

56. Muhire BM, Varsani A, Martin DP (2014) SDT: a virus classification tool based on pairwise sequence alignment and identity calculation. PLoS One 9:e108277

57. Niagro FD, Forsthoefel AN, Lawther RP, Kamalanathan L, Ritchie BW, Latimer KS, Lukert PD (1998) Beak and feather disease virus and porcine circovirus genomes: intermediates between the geminiviruses and plant circoviruses. Arch Virol 143:1723-1744

58. Noteborn MHM, Koch G (1995) Chicken anemia virus infection: molecular basis of pathogenicity. Avian Pathol 24:11-31

59. Padilla-Rodriguez M, Rosario K, Breitbart M (2013) Novel cyclovirus discovered in the Florida woods cockroach Eurycotis floridana (Walker). Arch Virol 158:1389-1392

60. Peters MA, Jackson DC, Crabb BS, Browning GF (2002) Chicken anemia virus VP2 is a novel dual specificity protein phosphatase. J Biol Chem 277:39566-39573
61. Phan TG, Li L, O'Ryan MG, Cortes H, Mamani N, Bonkoungou IJO, Wang C, Leutenegger CM, Delwart E (2012) A third gyrovirus species in human faeces. J Gen Virol 93:1356-1361

62. Phan TG, Phung Vo N, Sdiri-Loulizi K, Aouni M, Pothier P, Ambert-Balay K, Deng X, Delwart E (2013) Divergent gyroviruses in the feces of Tunisian children. Virology 446:346-348

63. Phan TG, Luchsinger V, Avendano LF, Deng X, Delwart E (2014) Cyclovirus in nasopharyngeal aspirates of Chilean children with respiratory infections. J Gen Virol 95:922-927

64. Phan TG, Mori D, Deng X, Rajindrajith S, Ranawaka U, Fan Ng TF, Bucardo-Rivera F, Orlandi P, Ahmed K, Delwart E (2015) Small circular single stranded DNA viral genomes in unexplained cases of human encephalitis, diarrhea, and in untreated sewage. Virology 482:98-104

65. Prasetyo AA, Kamahora T, Kuroishi A, Murakami K, Hino S (2009) Replication of chicken anemia virus (CAV) requires apoptin and is complemented by VP3 of human torque teno virus (TTV). Virology 385:85-92

66. Rijsewijk FAM, dos Santos HF, Teixeira TF, Cibulski SP, Varela APM, Dezen D, Franco AC, Roehe PM (2011) Discovery of a genome of a distant relative of chicken anemia virus reveals a new member of the genus Gyrovirus. Arch Virol 156:1097-1100

67. Rinder M, Schmitz A, Peschel A, Korbel R (2015) Complete genome sequence of a novel circovirus from zebra finch. Genome Announc 3:e00560-15

68. Ritchie BW, Niagro FD, Lukert PD, Steffens WL, Latimer KS (1989) Characterization of a new virus from cockatoos with psittacine beak and feather disease. Virology 171:83-88

69. Ritchie BW, Niagro FD, Latimer KS, Lukert PD, Steffens WL 3rd, Rakich PM, Pritchard N (1990) Ultrastructural, protein composition, and antigenic comparison of psittacine beak and feather disease virus purified from four genera of psittacine birds. J Wildl Dis 26:196-203

70. Rosario K, Marinov M, Stainton D, Kraberger S, Wiltshire EJ, Collings DA, Walters M, Martin DP, Breitbart M, Varsani A (2011) Dragonfly cyclovirus, a novel single-stranded DNA virus discovered in dragonflies (Odonata: Anisoptera). J Gen Virol 92:1302-1308

71. Rosario K, Dayaram A, Marinov M, Ware J, Kraberger S, Stainton D, Breitbart M, Varsani A (2012) Diverse circular ssDNA viruses discovered in dragonflies (Odonata: Epiprocta). J Gen Virol 93:2668-2681

72. Rosario K, Duffy S, Breitbart M (2012) A field guide to eukaryotic circular single-stranded DNA viruses: insights gained from metagenomics. Arch Virol 157:1851-1871

73. Sato G, Kawashima T, Kiuchi M, Tohya Y (2015) Novel cyclovirus detected in the intestinal contents of Taiwan squirrels (Callosciurus erythraeus thaiwanensis). Virus Genes 51:148-151

74. Sauvage V, Cheval J, Foulongne V, Gouilh MA, Pariente K, Manuguerra JC, Richardson J, Dereure O, Lecuit M, Burguiere A, Caro V, Eloit M (2011) Identification of the first human Gyrovirus, a virus related to chicken anemia virus. J Virol 85:7948-7950

75. Simmonds PM, AMJ, Benkő M, Breitbart M, Brister JR, Carstens EB, Davison AJ, Delwart E, Gorbalenya AE, Harrach B, Hull R, King AMQ, Koonin EV, Krupovic M, Kuhn JH, Lefkowitz EJ, Nibert ML, Orton R, Roossinck MJ, Sabanadzovic S, Sullivan MB, Suttle CA, Tesh RB, van der Vlugt RA, Varsani A, Zerbini FM (in press) Virus taxonomy in the age of metagenomics. Nature Rev Microbiol. doi:10.1038/nrmicro.2016.1177

76. Smits SL, Zijlstra EE, van Hellemond JJ, Schapendonk CM, Bodewes R, Schurch AC, Haagmans BL, Osterhaus AD (2013) Novel cyclovirus in human cerebrospinal fluid, Malawi, 2010-2011. Emerg Infect Dis 19:1511-1513

77. Steinfeldt T, Finsterbusch T, Mankertz A (2006) Demonstration of nicking/joining activity at the origin of DNA replication 
associated with the Rep and Rep' proteins of porcine circovirus type 1. J Virol 80:6225-6234

78. Stewart ME, Perry R, Raidal SR (2006) Identification of a novel circovirus in Australian ravens (Corvus coronoides) with feather disease. Avian Pathol 35:86-92

79. Takahashi K, Iwasa Y, Hijikata M, Mishiro S (2000) Identification of a new human DNA virus (TTV-like mini virus, TLMV) intermediately related to TT virus and chicken anemia virus. Arch Virol 145:979-993

80. Tan le V, van Doorn HR, Nghia HD, Chau TT, Tu le TP, de Vries M, Canuti M, Deijs M, Jebbink MF, Baker S, Bryant JE, Tham NT, NT BK, Boni MF, Loi TQ, Phuong le T, Verhoeven JT, Crusat M, Jeeninga RE, Schultsz C, Chau NV, Hien TT, van der Hoek L, Farrar J, de Jong MD (2013) Identification of a new cyclovirus in cerebrospinal fluid of patients with acute central nervous system infections. mBio 4:e00231-00213

81. Todd D, Creelan JL, Mackie DP, Rixon F, Mcnulty MS (1990) Purification and biochemical characterization of chicken anemia agent. J Gen Virol 71:819-823

82. Todd D, Niagro FD, Ritchie BW, Curran W, Allan GM, Lukert PD, Latimer KS, Steffens WL 3rd, McNulty MS (1991) Comparison of three animal viruses with circular single-stranded DNA genomes. Arch Virol 117:129-135

83. Todd D (2000) Circoviruses: immunosuppressive threats to avian species: a review. Avian Pathol 29:373-394

84. Todd D, Weston J, Ball NW, Borghmans BJ, Smyth JA, Gelmini L, Lavazza A (2001) Nucleotide sequence-based identification of a novel circovirus of canaries. Avian Pathol 30:321-325

85. Todd D, Weston JH, Soike D, Smyth JA (2001) Genome sequence determinations and analyses of novel circoviruses from goose and pigeon. Virology 286:354-362
86. Todd D, Scott ANJ, Fringuelli E, Shivraprasad HL, Gavier-Widen D, Smyth JA (2007) Molecular characterization of novel circoviruses from finch and gull. Avian Pathol 36:75-81

87. Varsani A, Martin DP, Navas-Castillo J, Moriones E, HernandezZepeda C, Idris A, Zerbini FM, Brown JK (2014) Revisiting the classification of curtoviruses based on genome-wide pairwise identity. Arch Virol 159:1873-1882

88. Varsani A, Navas-Castillo J, Moriones E, Hernandez-Zepeda C, Idris A, Brown JK, Murilo Zerbini F, Martin DP (2014) Establishment of three new genera in the family Geminiviridae: Becurtovirus, Eragrovirus and Turncurtovirus. Arch Virol 159:2193-2203

89. Varsani A, Krupovic M (in press) Sequence-based taxonomic framework for the classification of uncultured single-stranded DNA viruses of the family Genomoviridae. Virus Evol

90. Wu Z, Ren X, Yang L, Hu Y, Yang J, He G, Zhang J, Dong J, Sun L, Du J, Liu L, Xue Y, Wang J, Yang F, Zhang S, Jin Q (2012) Virome analysis for identification of novel mammalian viruses in bat species from Chinese provinces. J Virol 86:10999-11012

91. Wu Z, Yang L, Ren X, He G, Zhang J, Yang J, Qian Z, Dong J, Sun L, Zhu Y, Du J, Yang F, Zhang S, Jin Q (2016) Deciphering the bat virome catalog to better understand the ecological diversity of bat viruses and the bat origin of emerging infectious diseases. ISME J 10:609-620

92. Zhang W, Li L, Deng X, Kapusinszky B, Pesavento PA, Delwart E (2014) Faecal virome of cats in an animal shelter. J Gen Virol 95:2553-2564 